

\title{
REFORÇAR A IDENTIDADE E A AUTORIDADE: AS CASAS dE COURÁS LIBERTOS EM VILA RICA e Mariana no século XVIII*
}

\author{
Moacir Rodrigo de Castro Maia iD \\ Universidade Federal de Minas Gerais
}

Quando não souberes para onde ir, olha para trás e saiba pelo menos de onde vens.

Provérbio africano

$\mathrm{N}$ este artigo, reduzimos a escala de observação e analisamos um grupo de africanos libertos que enfrentaram a diáspora e passaram da escravidão para a liberdade em dois importantes núcleos da América portuguesa setecentista: Vila Rica de Ouro Preto e a cidade de Mariana (antiga Vila do Carmo), na capitania de Minas Gerais. ${ }^{1}$

Como tem enfatizado a historiografia, a urbanização e a economia baseada na mineração contribuíram para o crescimento do segmento de

* O texto é parte modificada do quarto capítulo de minha tese de doutorado, financiada pelo Conselho Nacional de Desenvolvimento Científico e Tecnológico (CNPq) e pela Coordenação de Aperfeiçoamento do Pessoal de Nível Superior (Capes), intitulada "De reino traficante a povo traficado: a diáspora dos courás do Golfo do Benim para as minas de ouro da América portuguesa (1715-1760)”, defendida no Programa de Pós-graduação em História Social da Universidade Federal do Rio de Janeiro (UFRJ) em dezembro de 2013.

1 Os termos de Vila Rica de Ouro Preto e de Mariana (Vila do Carmo) representaram, nas primeiras décadas e até meados do século XVIII, as áreas com a maior população escravizada da capitania, representando $50 \%$ ou mais da mão de obra de todo o território. Ver Anthony John R. Russell-Wood, Escravos e libertos no Brasil colonial, Rio de Janeiro: Civilização Brasileira, 2005, p. 163; Douglas Cole Libby, “As populações escravas das Minas Gerais Setecentistas: um balanço preliminar” in Maria Efigênia Lage de Resende e Luiz Carlos Villalta (orgs.), História de Minas Gerais: as Minas Setecentistas (Belo Horizonte: Autêntica; Companhia do Tempo, 2007), pp. 407-438. 
indivíduos forros nas comunidades mineiras ao longo do século XVIII. ${ }^{2}$ É nesse contexto que enfocamos um grupo específico de africanos libertos e acompanhamos cada um deles em diversas fontes documentais para entender como formaram uma classe de senhores ex-escravos. Nessas sociedades mineradoras, alguns desses indivíduos passaram a ser senhores e constituíram suas casas mesmo com toda adversidade que vivenciaram. Nosso olhar, então, se dirige para a compreensão desses lares. Como esses senhores africanos estabeleceram seus domicílios? Quais indivíduos passaram a integrar esses novos lares desse lado do Atlântico?

No Antigo Regime português, família tinha um sentido semântico expandido incluindo membros consanguíneos, agregados e indivíduos em situação de escravidão, este era o sentido da casa. ${ }^{3}$ Na outra margem do Atlântico, na África Ocidental, na chamada “terra de Courá”, havia complexas formas de organização familiar (huedo, hennu, ako), marcadas pela patrilinearidade e na qual indivíduos mais poderosos constituíam famílias provavelmente mais extensas que as encontradas no reino português. ${ }^{4}$

Este estudo enfoca um grupo específico de senhores africanos para perceber se haviam estabelecido alguma preferência na aquisição de trabalhadores escravizados. Dessa maneira, investigamos se existiu um sentimento identitário sendo criado ou recriado e que influenciaria na constituição desses lares africanos em Vila Rica de Ouro Preto e Mariana. Como teceram relações intraétnicas entre ex-escravizados e pessoas que permaneciam na escravidão?

Serão analisados os sujeitos africanos que se autodeclararam ou foram identificados como courá, coirá ou variantes (courano e coirano) em Vila Rica de Ouro Preto e Mariana. ${ }^{5}$ Essa identidade também foi mencionada em outros

2 Ver, por exemplo, Russell-Wood, Escravos e libertos no Brasil colonial; Eduardo França Paiva, Escravos e libertos nas Minas Gerais do século XVIII: estratégias de resistência através de testamentos, São Paulo: Annablume, 1995.

3 António Manoel Hespanha e Ângela Barreto Xavier, “As redes clientelares” in José Mattoso (org.), História de Portugal (Lisboa: Estampa, 1998), v. 4, pp. 381-393.

4 Luis Nicolau Parés, $O$ rei, o pai e a morte: a religião vodum na antiga Costa dos Escravos na África Ocidental, São Paulo: Companhia das Letras, 2016, pp. 46-51.

5 Anteriormente, analisamos as redes de parentesco ritual tecidas por couranos no apadrinhamento de courás adultos recém-chegados a Mariana na primeira metade do século XVIII. Fernanda 
espaços da América lusa ao longo do século XVIII. Luiz Mott encontrou um grupo de courás reunidos em honra "ao deus de sua terra” nas minas de Paracatu no nordeste da capitania de Minas Gerais em 1747. Mott revelou ainda a extraordinária trajetória da courana Rosa Egipcíaca de Vera Cruz que viveu no Inficcionado (Mariana) e outras partes de Minas Gerais, Rio de Janeiro e Lisboa setecentistas. Ainda em Minas Gerais, na comarca do Serro do Frio, Francisco Vidal Luna mencionou 791 courá ou coura-mina em uma lista de matrícula de trabalhadores escravos em 1738, em que provavelmente o número era bem maior. Stuart Schwartz apontou a presença de alguns mina-couranos na Bahia em registros de alforria emitidos entre 1684-1745. Luis Nicolau Parés anotou o etnônimo ao analisar inventários do Recôncavo da Bahia datados de 1733. Carlos Silva Júnior informou a presença de uma courana em auto de partilha de Salvador em 1735. Mais recentemente, no sertão baiano de Rio de Contas, Kátia Almeida encontrou mulheres e homens courana ou coura-mina em uma lista da população escravizada (1748-1749) e nos inventários post-mortem (1724-1810), onde havia 31 homens e 8 mulheres. Na cidade do Rio de Janeiro, em documentos paroquiais, que geralmente registravam africanos do Golfo do Benim como mina, Carlos Eugênio Soares encontrou um africano adulto mencionado como courá batizado na igreja da Candelária entre 1734 e 1744. Ainda no Rio de Janeiro, Mariza Soares registra a presença de quatro adultos couranos e duas crianças, filhas de mães couranas, entre 1751 e 1760 . Em Pernambuco, Josinaldo Queiroz encontrou o casal Luzia Barbosa e Francisco Xavier, moradores na rua Nova da Praia dos Coqueiros na Vila do Recife em 1740. Ambos foram identificados na documentação como de "nação coyrana, e do gentio da Costa da Mina”. Clara Araújo informou que há inventários post-mortem

Domingos Pinheiro reconstruiu a destacada inserção de courás como confrades da Irmandade do Rosário dos Pretos de Mariana entre 1745 e 1820. Cf. Fernanda Aparecida Domingos Pinheiro, "Confrades do Rosário: sociabilidade e identidade étnica em Mariana - Minas Gerais (1745-1820)”, Dissertação (Mestrado em História), Universidade Federal Fluminense, Niterói, 2006. Ver também Moacir Rodrigo de Castro Maia, “'Quem tem padrinho não morre pagão’: as relações de compadrio e apadrinhamento de escravos numa Vila Colonial (Mariana, 1715-1750)”, Dissertação (Mestrado em História), Universidade Federal Fluminense, Niterói, 2006, cap. 2; e "O apadrinhamento de africanos em Minas Colonial: o (re)encontro africano nas Américas (Mariana, 1715-1750)”, Afro-Ásia, v. 36 (2007), pp. 39-80 đo. No século XVIII, a variação encontrada em courá/coirá era comum na língua portuguesa. 
do Recife em que couranos são declarados e supõe que eles fariam parte das nações encontradas na Irmandade do Rosário da cidade no período (1776-1817). ${ }^{6}$ Courana e coirano ${ }^{7}$ também são encontrados na documentação portuguesa sobre o Golfo do Benim e são citados como inimigos do reido Daomé, nas décadas de 1740 e $1760,{ }^{8}$ e em relatos de traficantes escravistas que comerciavam naquela região da África Ocidental.

Conforme pesquisa anterior, revelamos que os termos couranas e coiranos foram utilizados pelos portugueses para designar os habitantes do reino de Uidá. ${ }^{9}$ A nossa pesquisa sobre esse grupo de origem africana, em Mariana

6 Luiz Mott, “Acotundá: raízes setecentistas do sincretismo religioso afro-brasileiro”, Revista do Museu Paulista, v. 31 (1986), pp. 124-147; e Rosa Egipcíaca: uma santa africana no Brasil, Rio de Janeiro: Bertrand do Brasil, 1993; Francisco Vidal Luna, "Minas Gerais: escravos e senhores. Análise da estrutura populacional e econômica de alguns centros mineratórios (1718-1804)”, Tese (Doutorado em Economia), Universidade de São Paulo, São Paulo, 1980, p. 124; Stuart B. Schwartz, Escravos, roceiros e rebeldes, Bauru: EDUSC, 2001, p. 187. Luis Nicolau Parés, A formação do Candomblé: história e ritual da nação jeje na Bahia, Campinas: Editora da Unicamp, 2007, p. 96 n. 12; Carlos Francisco da Silva Júnior, "Identidades afro-atlânticas: Salvador, século XVIII (1700-1750)", Dissertação (Mestrado em História Social), Universidade Federal da Bahia, Salvador, 2011, p. 216; Kátia Lorena Novais Almeida, "Escravos e libertos nas minas do Rio de Contas - Bahia, século XVIII”, Tese (Doutorado em História), Universidade Federal da Bahia, Salvador, 2012, p. 79; Carlos Eugênio Líbano Soares, "Uma porta para o mundo atlântico: africanos na freguesia da Candelária da cidade de São Sebastião do Rio de Janeiro, século XVIII”, Revista do Arquivo Geral da Cidade do Rio de Janeiro, n. 9 (2015), p. 53. Mariza de Carvalho Soares, Devotos da cor, Rio de Janeiro: Civilização Brasileira, 2000, p. 255 n. 33; Josinaldo Sousa de Queiroz, "Entre a permissão e a proibição: conflitos entre africanos, capuchinhos italianos e a administração secular na capitania de Pernambuco (1778-1797)”, Dissertação (Mestrado em História), Universidade Federal de Pernambuco, Recife, 2018, p. 86; Clara Maria F. de Araújo, "Governadores das nações e corporações: cultura política e hierarquias de cor em Pernambuco (1776-1817)”, Dissertação (Mestrado em História), Universidade Federal Fluminense, Niterói, 2007, p. 101 n. 26.

7 Alguns africanos que vivenciaram a experiência da escravidão em Minas Gerais, quando respondiam qual era a sua "terra" ou "nação" diziam ser naturais de "uma terra chamada Courá". O uso do sufixo de língua gbe "nu" - grafado em português como "no" - indicando "gente de" ou "da terra de" complementaria a palavra Courá, indicando ser "gente de Courá".

8 Arquivo Histórico Ultramarino (AHU), Lisboa, Série S. Tomé, cx. 5, Relatório da prisão de João Basílio e da destruição do forte de Ajudá, 29 out. 1744. No original consultado, os inimigos são chamados de Couranas e o termo foi alterado na publicação de Pierre Verger, Fluxo e refluxo do tráfico de escravos entre o golfo do Benin e a Bahia de Todos os Santos dos séculos XVII a XIX, 4e ed., São Paulo: Corrupio, 2002, pp. 228-229 n. 30, 225-226.

9 Moacir Rodrigo de Castro Maia, "De reino traficante a povo traficado: a diáspora dos courás do Golfo do Benim para as minas de ouro da América portuguesa (1715-1760)”, Tese (Doutorado em História Social), Universidade Federal do Rio de Janeiro, Rio de 
e Vila Rica de Ouro Preto, evidenciou a ausência de referências significativas a outros grupos da região costeira do Golfo do Benim, nas duas localidades mineiras, durante o século XVIII. Isso nos leva a crer que a identidade courá-courana pode ter se tornado um pouco mais inclusiva na diáspora.

Uidá (também conhecido pelos europeus como Ajudá, Juda, Juida, Iura, Whydah e Fida) emergiu como um importante reino do litoral do Golfo do Benim no final do século XVII e atingiu seu auge no início do século XVIII. Era o crescente papel de Uidá como centro de comercialização e de atividades ligadas ao tráfico transatlântico de pessoas escravizadas que produzia riqueza e atraía diferentes povos africanos e europeus para seus domínios. O reino e seu porto, também conhecido como Uidá, tornou-se o principal embarcadouro de cativos de todo o Golfo do Benim (Figura 1), na virada do século e nas primeiras décadas do Setecentos, quando o tráfico atingiu o seu maior volume. ${ }^{10}$ Contudo, as consequências da expansão do tráfico transatlântico na região levaram à queda do reino de Uidá, em 1727, e também do reino de Aladá, em 1724, para os daomeanos. ${ }^{11} \mathrm{O}$ papel da produção do cativeiro, particularmente pela guerra, foi entregue ao interiorano reino do Daomé que, em seu poderio crescente, suplantou os dois estados que enfrentavam fortes tensões e divisões

Janeiro, 2013, cap. 1. Preferimos utilizar o nome Uidá para nos referirmos tanto ao reino quanto ao seu importante porto, vocabulário mais próximo do nome nativo Huedá (Xweda). Atualmente, Uidá integra a República do Benim.

10 A vila de Uidá teria nascido como assentamento agrícola, como sugere o seu nome nativo (Glehue). Robin Law, Ouidah: The Social History of a West African Slaving 'Port', 1727-1892, Athens: Ohio University Press; Oxford: James Currey, 2004, pp. 26, 30. Elisée Soumonni, Daomé e o mundo Atlântico, Rio de Janeiro: CEAA/UCAM; Amsterdã: Sephis, 2001, p. 39. Se as fortes ondas do mar tornavam a navegação em sua costa um empreendimento perigoso, e muitas vezes mortal, a inusitada situação geográfica de Uidá, afastada quatro quilômetros da praia, transformava-a em intermediária natural nas trocas de mercadorias com o interior e com as povoações costeiras. A ampla lagoa que a separava da praia permitia, desde antes da chegada dos europeus, que se negociasse peixes e sal em troca de diversos bens, como tecidos e cativos. Pelo sistema de lagunas que se estendia pelo litoral, era possível, por exemplo, a chegada de pessoas escravizadas embarcadas em canoas vindas de Onim, a leste, ou de Pequeno Popo, a oeste. Robin Law, "Between the Sea and the Lagoons: The Interaction of Maritime and Inland Navigation on the Precolonial Slave Coast”, Cahiers d'Études Africaines, v. 29, 1989, pp. 209-237 ש.

11 Robin Law, "Warfare on the West Slave Coast, 1650-1850" in Brian Ferguson e Neil L. Whitehead (eds.), War in the Tribal Zone (Santa Fé: School of American Research Press, 1992), pp. 103-126. Law, Ouidah, p. 49. Em 1732, o território de Jakin foi conquistador pelo Daomé. 
políticas internas. ${ }^{12} \mathrm{O}$ governo de Agajá (c.1716-1740) era associado a essa expansão comercial e militar, celebrada pelo nome Dosou Hounyito (tomador de navios) e pelo emblema de seu reinado, representado por um navio europeu. ${ }^{13}$

Figura 1

Parte Ocidental do “Golfo do Benim”, final do século XVII e início do século XVIII ${ }^{14}$

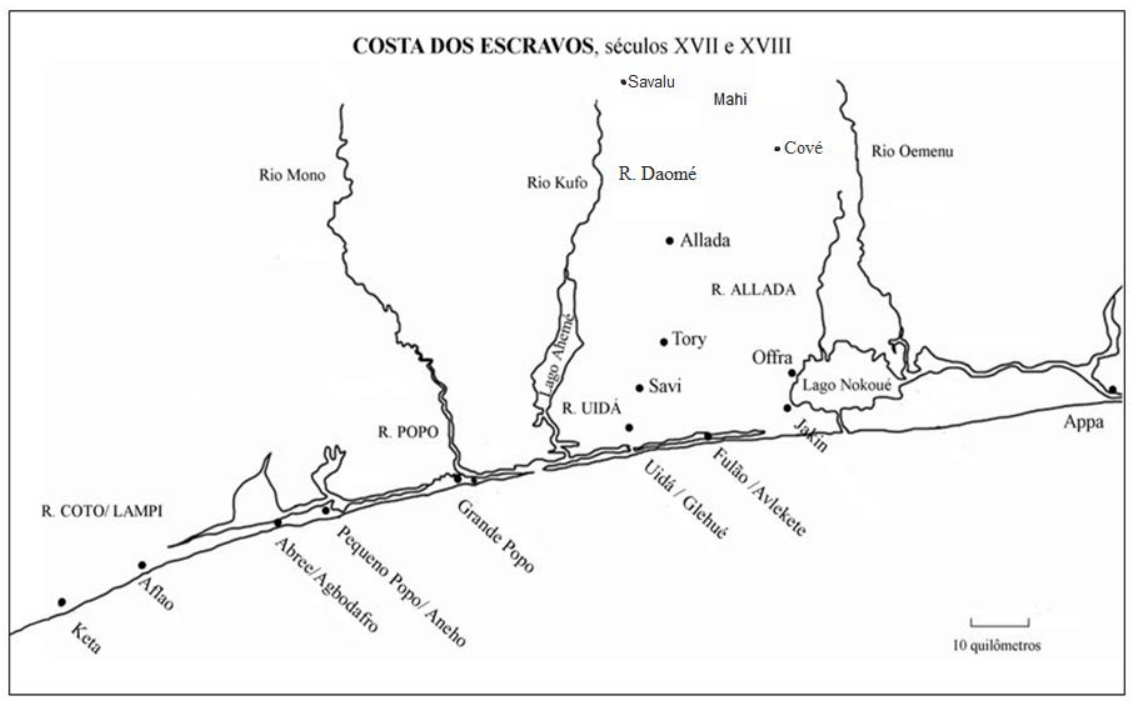

12 Robin Law, “'The Common People Were Divided’: Monarchy, Aristocracy and Political Factionalism in the Kingdom of Whydah, 1671-1727”, International Journal of African Historical Studies, v. 23 (1990), p. $201 \mathrm{dol}$.

13 Auguste Le Hérissé, L'Ancièn Royaume du Dahomey: moeurs, religion, histoire, Paris: Émile Larose, 1911, p. 16. Na invasão a Uidá, em 1727, as tropas de Agajá teriam assassinado mais de cinco mil habitantes e fizeram mais de dez mil prisioneiros, que foram sacrificados (principalmente os mais velhos e os muitos jovens), ofertados às elites do reino Fon ou vendidos aos europeus. Os que não conseguiram fugir continuaram no território ou acabaram negociados para o tráfico transatlântico. Os que conseguiram escapar partiram em exílio para a costa do Lago Ahémé e para diversas localidades costeiras a leste do Golfo do Benim, iniciando outra intensa fase de migrações, demarcações de fronteiras étnicas, compartilhamento de ações políticas e de incorporação em novos grupos sociais. Parcela dos uidás manteve-se sob o governo da antiga dinastia e, por mais de quatro décadas, lutaram pela reconquista do antigo território. A situação de calamidade no exílio obrigou famílias a venderem suas mulheres, filhos, agregados e escravos aos traficantes europeus. Law apresenta, com detalhes e profundidade, os embates entre os exilados de Uidá e os daomeanos, ao longo do século XVIII (Cf. Law, Ouidah, pp. 50-68).

14 Luis Nicolau Parés (org.), "Mapas”, Práticas religiosas na Costa da Mina, uma sistematização das fontes europeias pré-coloniais, 1600-1730 〔 (mapa adaptado). 
A presença de muitos africanos identificados como courás ou couranos em Minas Gerais, ao longo do século XVIII, é consequência principalmente da queda do reino de Uidá e da expansão daomeana sobre o litoral do Golfo do Benim.

Em Minas Gerais, os courás e couranos também foram muitas vezes identificados de modo geral como africanos minas e em vários casos aparecem até mesmo como mina-courá ou mina-courano, como um subgrupo mina. Isso também aconteceu com outros grupos do interior do Golfo do Benim declarados como mina-fon, mina-ladá, mina-cobu, mina-sabaru, por exemplo. No contexto do Império Português, apontavam ou eram apontados como vindos da chamada Costa da Mina.

A chamada Costa da Mina inicialmente remetia à região da instalação do Castelo de São Jorge da Mina (1482) e à povoação do seu entorno na Costa do Ouro, na África Ocidental. Contudo, para os habitantes de Minas Gerais, na América portuguesa, ela tinha seu alcance semântico bem ampliado durante o século XVIII. Ela poderia abranger a Costa do Marfim, a Costa do Ouro, o Golfo do Benim (conhecido por outras nações europeias como a Costa dos Escravos), e ir além, incluindo a Baía de Biafra. Os africanos minas, em Minas Gerais, nesse período, poderiam ser desde axantes até igbos ou calabaris. ${ }^{15}$

Se a abrangência espacial da Costa da Mina era significativa no século XVIII, eram da Costa a Sotavento ${ }^{16}$ e, mais precisamente, do Golfo do Benim e do seu interior, muitos dos grupos escravizados estabelecidos em Vila Rica de Ouro Preto, na vizinha Mariana, na comarca do Serro do Frio e em outras vilas e arraiais de Minas Gerais ainda na primeira metade do século. Nestas duas localidades, em duas listas com nomes de pessoas escravizadas, emergem termos que, no Golfo do Benim, fazem referência a reinos, cidades importantes, grupos e etnias do interior e do litoral. Dentre eles, aparecem:

15 Maia, “De reino traficante a povo traficado”, p. 107.

16 A conhecida expressão utilizada por Pierre Verger para marcar a mudança do eixo do tráfico transatlântico de escravos da Costa do Ouro em direção a leste é muito atual e pertinente. Verger, Fluxo e refluxo, p. 37. 
courá ou coirá; cobu; ${ }^{17}$ ladano; ${ }^{18}$ fon; ${ }^{19}$ sabaru; ${ }^{20}$ anagô ou nagô; ${ }^{21}$ com seus respectivos variantes.

17 Cobu (cobú, coubu, cubu) remete a Cové, cidade importante da região dos Agonlis (Agonli-Cové), a leste de Abomé (Daomé) - cujos habitantes são tidos como povos mahis. Yeda Pessoa de Castro, A língua mina-jeje no Brasil: um falar africano em Ouro Preto do século XVIII, Belo Horizonte: Fundação João Pinheiro, Secretaria de Estado da Cultura, 2002, pp. 131-132. Na listagem de pessoas escravizadas do termo de Mariana (1723) e nos dados do distrito diamantino (1738), os cobus aparecem como subgrupo mina e numericamente expressivos. Maia, "De reino traficante a povo traficado”, cap. 2.

18 Ladano ou ladana (ladá, ardrá e arda), remete ao reino de Aladá. O primeiro registro consta nas listas de pessoas escravizadas de Ouro Preto e Mariana em 1718. Maia, "O apadrinhamento de africanos em Minas colonial", pp. 47-48.

19 O termo fon (fono e fom) faz referência ao reino fon do Daomé - sendo a primeira nomeação na América portuguesa na lista dos quintos de Mariana, em 1723, antes da expansão daomeana sobre o litoral. Maia, "O apadrinhamento de africanos em Minas colonial”, pp. 47-48.

20 Sabaru (sabarú, sabará e mina sabarú) vem de Savalu (Savalou, em francês), cidade e antigo reino, ao norte do Daomé. Seria formada por grupos de língua gbe que se estabeleceram na região habitada por grupos de origem protoiorubá. Para alguns especialistas é considerada parte do "país mahi”. Os Gbaguidi, família real de Savalu, defendem que seus antepassados originalmente eram huedás. No Brasil, savalu se tornou uma modalidade/rito do chamado Candomblé Jeje-Savalu. Parés, A formação do Candomblé, p. 40. Até o momento, a informação mais antiga sobre este grupo na América portuguesa consta no registro de povoados do termo de Mariana, temos a presença de quatro escravizados sabarus, em 1723. A presença desse etnônimo em Minas Gerais, antes mesmo de que fosse conhecido nos documentos do tráfico atlântico em Uidá, em 1733, mostra que indivíduos ao norte do Daomé começavam a se estabelecer em Minas Gerais antes da década de 1720, revelando a presença do tráfico de escravos naquela região africana. Maia, "De reino traficante a povo traficado", pp. 113-114.

21 Anagô ou nagô (nagoâ e nagom) designava pequeno grupo instalado na região de Egbado e a oeste do rio Weme, na atual Nigéria. Com o tempo, Nagô passou a designar pluralidade de grupos falantes de línguas protoiorubás. Na República do Benim, os iorubás são chamados de nagô, anagô e nagonu (povo nagô). Robin Law, "Ethnicity and the Slave Trade: 'Lucumi' and 'Nago' as Ethnonyms in West Africa”, History in Africa, v. 24 (1997), pp. 205-219 đọ; Parés, A formação do Candomblé, pp. 25-27. Vila Rica de Ouro Preto (1718) e Mariana (1723) registram os primeiros africanos tidos, no Brasil, como nagôs, anagôs e seus variantes (nove em Vila Rica, quinze em Mariana, todos homens). Maia, "De reino traficante a povo traficado", p. 111. Na Bahia, eles estão identificados pela primeira vez como nagô, no Recôncavo Baiano, em 1734. Luis Nicolau Parés, "O processo de 'nagoização' do Candomblé baiano” in Lígia Bellini, Gabriela dos Reis Sampaio e Everton Sales Souza (orgs.), Formas de crer: ensaios de história religiosa do mundo luso-afro-brasileiro, séculos XVI-XXI (Salvador: Edufba; Corrupio, 2006), p. 304. Essa menção é contemporânea à descrição dos nagôs no porto de Uidá, pelo navegador francês Des Marchais, publicada em 1730 por Labat. Des Marchais apud Jean-Baptiste Labat, Voyage du Chevalier des Marchais en Guinée, isles voisines et à Cayenne, fait em 1725, 1726 et 1727, Amsterdã: Aux dépens de la Compagnie, 1731 (Paris, 1730), t. 2, pp. 101-102. 
A formação da identidade mina entre grupos e povos heterogêneos, na capitania de Minas Gerais e em outras partes da América portuguesa, decerto, passou pelo compartilhamento da linguagem. A possibilidade é a de que grupos linguisticamente aparentados, como os gbes do Golfo do Benim, muitos dos quais falantes de dois ou mais idiomas, aproximaram-se, certamente, dos escravizados recém-chegados, permitindo a interação social e a sociabilidade pela linguagem. Foi esse reconhecimento que acabou por gerar a formação de uma língua geral dos minas - talvez percebida já no litoral do Golfo do Benim. E essa "língua franca”, comum nas lavras, casas, ruas, estradas, igrejas e comércio, foi registrada em um vocabulário em distrito pertencente à Vila Rica. ${ }^{22}$

\section{As casas de courás libertos em Vila Rica e Mariana ${ }^{23}$}

Ao falecer, em 1742, a liberta courana Rosa da Silva Torres, revelou, em seu testamento, o trabalho que tivera para escapar da escravidão e se tornar senhora de sua casa, na Vila do Carmo. Ela constituiu uma rede de relações de confiança que lhe permitiu fazer empréstimos e bons negócios, entrar na justiça pela proteção do patrimônio do filho e driblar as muitas dificuldades que enfrentou ao longo da vida. Com seu trabalho à frente de um pequeno empório, conseguiu comprar a liberdade do marido e, juntos, adquiriram casas, chácara com plantações e um serviço de minerar para extrair ouro, além de trabalhadores escravos.

22 O português Antônio da Costa Peixoto escreveu precioso vocabulário de "língua mina” baseado em coletas que realizou quando morava em um distrito de Vila Rica nas primeiras décadas do século XVIII. Esses manuscritos, elaborados entre 1731 e 1741, foram publicados pela primeira vez por Luís Silveira. Luís Silveira, Obra Nova de Língua Geral de Mina de Antônio da Costa Peixoto, Lisboa: Agência Geral das Colônias, 1945.

23 É importante destacar que para o estudo da trajetória desses africanos do grupo courá/courano foi necessário reunir uma diversidade de outras fontes documentais para além dos testamentos analisados. 
Ela chefiava um domicílio com mais de treze pessoas negras. Rosa, como muitas outras mulheres africanas, desenvolveu grande habilidade para o comércio. ${ }^{24}$ Alguns desses talentos para comerciar vieram como bagagem trazida de suas terras. Fosse no reino de Uidá, por exemplo, como no de Aladá ou em alguma cidade-estado iorubana, a participação feminina nos mercados era marcante,

predominava a venda de comida feita. E quase todas as barracas tinham atrás delas mulheres, que dominavam, como em outras partes da África, o comércio a retalho. Com um pano colorido enrolado à cintura e a descer até abaixo dos joelhos, de cabelos entrançados, e usando muitos colares, braceletes e tornozeleiras, elas amamentavam os bebês, vigiavam as crianças, fumavam seus longos cachimbos e comentavam as notícias do dia, enquanto esperavam os fregueses. ${ }^{25}$

Para além dos negócios e da compra de gêneros diversos, o pequeno comércio de secos e molhados, como o da courana Rosa da Silva Torres, era espaço para "bailes, batuques e folguedos [que] atraíam ao local camadas populares pobres em busca de um lazer coletivo", ${ }^{26}$ As vendas, chefiadas por mulheres africanas que pertenceram ao cativeiro e conseguiram a alforria, eram ambientes ideais para esses encontros e tinham papéis agregadores importantes para a comunidade africana. O Conde de Assumar, quando governou a capitania de São Paulo e Minas do Ouro, instalado em Vila do Carmo e Vila Rica

24 A participação de mulheres africanas em Minas Gerais Setecentista, particularmente, as africanas minas, no pequeno comércio é registrada em diversos trabalhos. Ver, por exemplo, André João Antonil, Cultura e opulência do Brasil, por suas drogas e minas, Rio de Janeiro: Typ. Imp. e Const. de J. Villeneuve e Ca., 1837. Luciano R. de Almeida Figueiredo, O avesso da memória: cotidiano e trabalho da mulher em Minas Gerais no século XVIII, Rio de Janeiro: José Olympio; Brasília: EdUnb, 1993.

25 Alberto da Costa e Silva, Francisco Félix de Souza, mercador de escravos, Rio de Janeiro: Nova Fronteira, 2012, p. 361.

26 Figueiredo, $O$ avesso da memória, p. 44. 
(1717-1721), observou que mulheres libertas abriam vendas "que pudessem ser locais de reunião de negros de sua 'nação'”. ${ }^{27} \mathrm{O}$ governador não estava enganado, mas talvez ele se impressionasse mais ao saber que, em alguns desses estabelecimentos comerciais chefiados por libertas e libertos nascidos na África, atrás do balcão de vendas haviam trabalhadores escravos do mesmo grupo étnico dos proprietários, muitos dos quais eram de fato conterrâneos.

A courana Rosa da Silva Torres, por exemplo, claramente manteve uma política de maior aquisição de escravos couranos. Em 1742, ela apresentou em seu testamento aqueles que trabalhavam na rocinha, na produção de farinha, na mineração e em seu comércio, no total de onze escravizados, sendo dez em idade produtiva (Quadro 1). Rosa da Silva Torres chefiava sua casa e tinha, entre seus escravos adultos: Luís, José, Manuel e Joana, todos couranos como a senhora. E a pequena Natália, filha de Joana courana. Rosa, ao ditar seu testamento, declarou: "Sou natural da Costa da Mina de nação coura”. Além de autoidentificar-se, evidenciou as fronteiras identitárias entre os membros de sua casa, por exemplo: Antônia era sabaru (savalu), Cristovão era cobu (agonli-covè) e Antônio era fom (fon) - outros três subgrupos mina da localidade (mina-sabaru; mina-cobu e mina-fon). Covè, Fon e Savalu são três outros nomes de reinos ou localidades do interior do Golfo do Benim - o que reforça a demarcação de fronteira identitária entre os africanos chamados mina vindos do interior daquela região da África Ocidental.

27 Russell-Wood, Escravos e libertos no Brasil colonial, p. 170. 
Quadro 1

A casa da courana liberta Rosa da Silva Torres em $1742^{28}$

\begin{tabular}{|c|c|c|c|}
\hline Nome & Condição social & Identidade & Informação complementar \\
\hline Rosa da Silva Torres & Forra & Courá & - \\
\hline $\begin{array}{c}\text { Antônio da Silva } \\
\text { Barbosa }\end{array}$ & Forro & Mina & Marido de Rosa da S. Torres \\
\hline Antônio pardo & Forro & Pardo & $\begin{array}{c}\text { Filho de Rosa com o } \\
\text { ex-senhor }\end{array}$ \\
\hline Teresa & Forra & Crioula & Filha de Rosa com o marido \\
\hline \multicolumn{4}{|l|}{ Escravos da casa: } \\
\hline José & Escravo & $\begin{array}{c}\text { Courá/ } \\
\text { Mina-courano }\end{array}$ & - \\
\hline Luís & Escravo & $\begin{array}{c}\text { Courá/ } \\
\text { Mina-courano }\end{array}$ & - \\
\hline Manuel & Escravo & $\begin{array}{c}\text { Courá/ } \\
\text { Mina-courano }\end{array}$ & - \\
\hline Joana & Escrava & $\begin{array}{c}\text { Courá/ } \\
\text { Mina-courana }\end{array}$ & $\begin{array}{l}\text { Escrava adulta batizada em } \\
1732\end{array}$ \\
\hline Natália & Escrava & Mulatinha & $\begin{array}{c}\text { Filha de Joana courá, idade } \\
\text { de } 7 \text { anos }\end{array}$ \\
\hline Maria & Escrava & $\begin{array}{l}\text { Mina/Mina-fom } \\
\text { (fon) }\end{array}$ & - \\
\hline Antônia & Escrava & $\begin{array}{c}\text { Mina/ } \\
\text { Mina-sabaru }\end{array}$ & - \\
\hline Cristovão & Escravo & Cobu/Mina-cobu & - \\
\hline Teresa & Escrava & $\begin{array}{l}\text { Mina/Mina-fom } \\
\text { (fon) }\end{array}$ & Casada com Agostinho \\
\hline Agostinho & Escravo & Angola & Marido de Teresa \\
\hline Manuel & Escravo & Angola & - \\
\hline
\end{tabular}

28 Arquivo Histórico da Casa Setecentista de Mariana (AHCSM), Mariana, $2^{\circ}$ Ofício, cód. 63, auto 1.426, Inventário de Rosa da Silva Torres, 22 out. 1742, fl. 17v-18. Nota: O testamento está anexado ao inventário dos bens e encontra-se também em: AHCSM, $1^{\circ}$ Ofício, livro de testamento $n^{\circ} 72$, de 16 out. 1742, fl. 76v-79v. No testamento ditado pela senhora aparece o termo courá ou nação courá. No inventário, os avaliadores, provavelmente seguindo as indicações do marido inventariante, descreveram todos os courás como mina-courano, da mesma forma, mina-sabaru e mina-cobu, mina-fom (fon). 
Essa política de compra de courás é percebida em outras moradias de libertos que vão se instalando em Mariana e, também, em Vila Rica. Os antigos vizinhos da africana Rosa da Silva Torres na rua do Piolho, o mina Damião de Oliveira e a courana Antônia Ferraz de Azevedo também possuíam trabalhadores couranos em sua casa. Em abril de 1729, dois anos após o casamento, Damião e Antônia mandaram batizar a escrava Rosa courana na Igreja Matriz da Vila do Carmo ${ }^{29} \mathrm{o}$ que indicaria que fosse uma acru hihõ (escrava nova) - como os de língua geral mina se referiam aos recém-chegados à região. ${ }^{30}$ Curiosamente, um mês depois, Maria courana, escrava de Francisco da Silva Leite, era também batizada na mesma igreja. As couranas Rosa e Maria foram identificadas em seus batizados, exatamente dois anos depois da expansão daomeana sobre o litoral do Golfo do Benim, na África. Provavelmente, suas diásporas faziam parte deste contexto de tensões naquela costa africana. Tempos depois, em Minas Gerais, a senhora courana Antônia Ferraz de Azevedo comprou Maria, escrava de Francisco da Silva Leite. Temos então, na casa dos pretos forros, Damião e Antônia, a reunião das duas escravizadas, Maria e Rosa que, possivelmente, chegaram à povoação na mesma época. Em 1743, passados quatorze anos do seu batismo, Maria courana foi libertada pelo casal Damião de Oliveira e Antônia Ferraz de Azevedo pelos bons serviços e pelo pagamento de 210 o itavas de ouro (315 mil réis). ${ }^{31}$

O courano Inácio Fagundes chegou à América portuguesa ainda jovem, certamente aportou no Rio de Janeiro e lá esteve por algum período até que seu senhor, o capitão Sebastião Fagundes Varela, o levou

29 Arquivo Eclesiástico da Arquidiocese de Mariana (AEAM), Mariana, livro O-4, Registro de Batismo de Rosa courana, 11 abr. 1728, fl. 23. Rosa teve como padrinhos João nagô, escravo de Miguel Gomes, e Ana mina, escrava de Rosa da Silva. Em 1750, ela continua escrava do casal de libertos Damião e Antônia, quando leva o filho Vitorino para ser batizado, tendo por padrinhos Francisco Mendes e a courana liberta Rita Ribeira (AEAM, livro O-5, Registro de Batismo de Vitorino inocente, 20 jul. 1750, fl. 127v).

30 Castro, A língua mina-jeje no Brasil, p. 182.

31 Escritura de alforria datada de 24 maio 1743 apud Pinheiro, "Confrades do Rosário", p. $153 \mathrm{n}$. 
para morar no seu sítio, nos arrabaldes do Monsus, em Vila do Carmo. Do Rio de Janeiro, lembrava-se do convento do Carmo, um dos primeiros edifícios que deve ter avistado quando aportou na cidade, e do colégio dos jesuítas no Morro do Castelo. Sebastião Fagundes Varela era um dos importantes potentados locais, procedente do Rio de Janeiro e que bem cedo se dirigiu para Minas Gerais e lá fez fortuna. Em 1718, sua posição social e seu prestígio tornaram-no o provedor encarregado da arrecadação do Quinto do ouro da sede de Vila do Carmo, controlando uma arrecadação aurífera das mais vultosas. Foi também o primeiro a dar o exemplo, ao arrolar o seu grande contingente de trabalhadores escravos. Inácio mina estava entre os 72 escravizados que residiam no sítio do Fagundes, nos arrabaldes do Monsus, o maior contingente escravista da povoação. O sítio do seu senhor era um pequeno mosaico da diversidade étnica africana que o ouro atraiu para o território das Gerais. ${ }^{32}$ Entre os companheiros de Inácio, encontramos aqueles que trabalhavam como barbeiros, sapateiros, cozinheiro, trombeteiro, além daqueles empregados como mineiros na grande lavra mineral do sítio do Fagundes, como o próprio Inácio.

Por ter "sempre servido com muito cuidado, zelo e diligência" e por se comprometer a pagar, em parcelas (quartação), o restante da avultada soma de 480 oitavas de ouro (576 mil réis), Inácio Fagundes negociou a alforria com o irmão do seu senhor, em fevereiro de 1726. Nesse documento, escrito e registrado em cartório, Inácio foi identificado como "um negro chamado Inácio de nação coirá”. ${ }^{33}$ Três anos depois, ele conseguiu quitar a alforria e, como não era usual, ele e o irmão do senhor voltaram ao cartório para celebrar nova e definitiva escritura, quando é nomeado "Inácio

32 Eram 30 minas, 1 mina maquiné, 6 cabo verdes, 1 São Tomé, 6 benguelas, 4 aloandas, 6 moçambiques, 4 congos, 2 crabarys, 1 barbâ, 1 monjolo, 1 massangano, 1 crioulo do Reino de Portugal, 2 mulatos, 2 pardos, 1 crioula, 3 sem identificação. Arquivo Público Mineiro (APM), Belo Horizonte, Seção Colonial, cód. 1.036, Reais quintos de 1718.

33 AHCSM, $1^{\circ}$ Ofício, livro de notas $\mathrm{n}^{\circ} 26$, Escritura de alforria de Inácio coirá, 7 fev. 1726, fl. 35v-36v. Inácio havia “dado duzentas e cinquenta e seis oitavas de ouro e lhe ficou a dever 144 oitavas de ouro, o que faz ao todo 480 oitavas de ouro, preço porque o coartara (quartara)”. 
courá"-possuidordodocumentodeliberdade, "livreeisentodeescravidão". ${ }^{34}$ O liberto Inácio que, como os demais, adotou o sobrenome do senhor passou a nomear-se oficialmente como Inácio Fagundes -, também buscou o casamento logo após a coartação, unindo-se à forra Luísa Batista da Cruz, de nação conga, em outubro de $1726 .{ }^{35}$

Inácio Fagundes permaneceu morando em uma casa no sítio do antigo e poderoso senhor, reforçando a autoridade de Sebastião Fagundes e tendo o benefício de tê-lo como protetor. A mineração garantiu meios para a compra da liberdade e, depois, para a aquisição de trabalhadores escravos. Em 1732, o liberto courano Inácio Fagundes, doente, preparou o seu testamento no qual declarou "ser natural da Costa da Mina e não tenho pai nem mãe por serem já defuntos”. ${ }^{36}$ Contudo, menciona o seu primo "Cosme courano" morador em um povoado próximo. Inácio era proprietário de uma "mina de sociedade no morro do arraial do Padre Faria em que sou sócio com um preto por nome Francisco que é escravo, na qual mina tenho a terça parte”, com seus instrumentos, em Vila Rica. Porém, os bens mais preciosos eram os escravos do casal: José, Francisca e Rita, todos de "nação courana"; ${ }^{37}$ José, de nação fono (fon); Quitéria mina; e quatro crianças, filhas das escravas Francisca (Ana e Manuel crioulos), Rita (Lourença crioulo) e Quitéria (Francisco crioulo) (Quadro 2).

34 De forma não usual, Inácio e o irmão do seu antigo senhor retornam ao cartório, três anos depois, para lavrar nova escritura e o valor total da sua alforria havia sido renegociado, visto ter quitado o valor total de 400 oitavas de ouro (480 mil réis) - que era um alto valor para uma alforria (AHCSM, $1^{\circ}$ Ofício, livro de notas n ${ }^{\circ} 33$, Escritura de alforria de Inácio courá, 21 abr. 1729, fl. 1-1v).

35 AEAM, livro O-2, Registro de casamento de Luiza Batista da Cruz e Inácio Fagundes, 6 out. 1726, fl. 70 .

36 AHCSM, $1^{\circ}$ Ofício, livro de testamento ${ }^{\circ} 73$, Testamento de Inácio Fagundes, 7 ago. 1732 (abertura em 16 fev. 1733), fl. 30v-32.

37 Após a morte de Inácio, Rita courana continuou pertencendo à viúva Luiza Batista, de nação conga. Em 1735, Rita foi registrada como mina no batismo do filho de Quitéria, que era escrava do casal Damião de Oliveira e Antônia Ferraz de Azevedo (AEAM, livro O-5, Registro de Batismo de Antônio inocente, 22 maio 1735, fl. 52), sendo que Rita e o padrinho Antônio mina, eram couranos, como evidenciam outros documentos. O padrinho Antônio courano tinha como alcunha "o cabeça”. Arquivo Nacional da Torre do Tombo (ANTT), Lisboa, Inquisição de Lisboa, 028, cx. 1.634, auto 16.921, Termo de assentada de padre Francisco Rodrigues Pereira contra António courano, 1733. 
Quadro 2

A casa do courano Inácio Fagundes em $1732^{38}$

\begin{tabular}{|cccc|}
\hline Nome & Condição social & Identidade & Informação complementar \\
\hline Luísa Batista da Cruz & Forro & Courano & - \\
\hline Escravos da casa: & Forra & Conga & Esposa de Inácio Fagundes \\
\hline Francisca & Escrava & Courana & $\begin{array}{c}\text { Escrava adulta } \\
\text { batizada em 1728 }\end{array}$ \\
\hline Rita & Escrava & Courana & - \\
\hline José & Escravo & Courano & "Moleque" \\
José & Escravo & Fono (Fon) & - \\
Quitéria & Escrava & Mina & - \\
Ana & Escrava & Crioulinha & $\begin{array}{c}\text { Filha da escrava Francisca } \\
\text { courana, nasc. 1729 }\end{array}$ \\
\hline Manuel & Escravo & Crioulinho & $\begin{array}{c}\text { Filho da escrava Francisca } \\
\text { courana, nasc. 1730 }\end{array}$ \\
\hline Lourença & Escrava & Crioulinha & $\begin{array}{c}\text { Filha da escrava Rita } \\
\text { courana, nasc. 1728 }\end{array}$ \\
\hline Francisco & Escravo & Crioulinho & $\begin{array}{c}\text { Filho da escrava Quitéria } \\
\text { mina, nasc. 1729 }\end{array}$ \\
\hline
\end{tabular}

Nas casas dos libertos Rosa da Silva Torres, em 1742, e de Inácio Fagundes, em 1732, os escravos nascidos no Brasil eram todos filhos de africanas escravas desses domicílios. O que podemos notar inicialmente é que houve um direcionamento para a aquisição de adultos nascidos na África, que eram a grande maioria dos moradores de Mariana e a principal mão de obra oferecida nos mercados escravistas nas primeiras décadas do século XVIII. Em Vila Rica (1718), mais de 91\% e, em Vila do Carmo (1723), 81\% eram de nascidos na África. ${ }^{39}$ Os termos de Vila Rica de Ouro Preto e de Vila do Carmo representaram, nas primeiras décadas e até

38 AHCSM, $1^{\circ}$ Ofício, livro de testamento $\mathrm{n}^{\circ} 73$, Testamento de Inácio Fagundes, de 7 ago. 1732 (abertura em 16 fev. 1733), fl. 30v-32. No testamento, Inácio se declara apenas como natural da Costa da Mina. Ele consta como courano em seu documento de alforria. AHCSM, $1^{\circ}$ Ofício, livro de notas ${ }^{\circ} 26$, Escritura de alforria de Inácio coirá, 7 fev. 1726, fl. 35v-36v.

39 Embora os números fossem maiores, visto que 3,5\% dos escravos em Vila Rica e 12\% em Vila do Carmo não tiveram suas origens anotadas. 
meados do século, as áreas com a maior população escrava da capitania, mobilizando $50 \%$ ou mais da mão de obra de todo o território. ${ }^{40}$

\section{A (re)construção de autoridade entre os courás}

Os lares constituídos pelos couranos libertos que localizamos, nas duas vilas, eram casas formadas por africanos e seus descendentes. Encontramos significativas informações ao analisarmos, particularmente, os testamentos desses indivíduos e os documentos de suas alforrias e de seus escravos. As mulheres na Minas Gerais setecentista, como demonstram estudos anteriores, mesmo não sendo maioria na população escravizada, foram as que mais tiveram acesso à alforria, particularmente, pela compra da liberdade pelo sistema da coartação. ${ }^{41}$ Os testamentos de couranos que localizamos refletem essa dinâmica: em Mariana, quinze mulheres e quatro homens; em Vila Rica, dez mulheres e dois homens, com testamentos. Ao analisarmos esses documentos, temos a revelação de que, quando ditaram suas últimas vontades e declararam seus bens, esses libertos haviam amealhado significativo patrimônio.

De modo geral, fica evidente que o passo seguinte à conquista da liberdade foi a busca por se tornar, também, senhor de escravos. Ser proprietário de escravos, além de signo que trazia certo status para esses homens e mulheres que viviam sob o estigma da escravidão, ao mesmo tempo, era uma das melhores opções para sobreviver com certa estabilidade, contando com trabalhadores a seu serviço. Tratava-se de investimento lucrativo. Quase a totalidade dos couranos forros que encontramos nos testamentos em Mariana e em Vila Rica tiveram escravos. Talvez seja um dos índices mais expressivos

40 Russell-Wood, Escravos e libertos no Brasil colonial, p. 163.

41 No termo de Mariana, foram 144 mulheres e 47 homens couranos - o primeiro registro de 1722 e o último em 1782. Sobre as alforrias e o sistema de coartação, pagamento em parcelas da manumissão, ver: Andréa Lisly Gonçalves, As margens da liberdade: estudo sobre a prática de alforrias em Minas colonial e provincial, Belo Horizonte: Fino Traço, 2011; Carlo G. Monti, “O processo de alforria: Mariana (1750-1779)”, Dissertação (Mestrado em História Social), Universidade de São Paulo, 2001; Paiva, Escravos e libertos nas Minas Gerais. 
encontrados, até o momento, sobre um grupo de africanos, ${ }^{42}$ malgrado ainda existirem poucas pesquisas sobre etnicidades relacionadas à propriedade escravista dos libertos. É fato que esses couranos não eram o segmento mais empobrecido entre os libertos, e mesmo em comparação com a população livre, como mostram o Quadro 3 e o Quadro 4. Há alguma ascensão e certa prosperidade financeira desses grupos de libertos no ambiente escravista, ainda que perpassada pelos ditames e restrições à ascensão social, dentro do quadro do Antigo Regime português. No quadro abaixo, reunimos 23 senhores libertos courás (19 mulheres e 4 homens) e arrolamos testamentos (19) e/ou documentos de alforria e batismo (4).

Quadro 3

Couranos libertos senhores de outros couranos, Mariana (Vila do Carmo) ${ }^{43}$

\begin{tabular}{|c|c|c|c|c|c|c|}
\hline Couranos forros & $\begin{array}{c}\text { Ano } \\
\text { da sua } \\
\text { alforria }\end{array}$ & $\begin{array}{c}\text { Ano do } \\
\text { testamento } \\
\text { ou outro } \\
\text { documento }\end{array}$ & Localidade & $\begin{array}{l}\text { Número } \\
\text { total de } \\
\text { escravos }\end{array}$ & $\begin{array}{l}\text { Escravos } \\
\text { couranos }\end{array}$ & $\begin{array}{c}\text { Quartação } \\
\text { courá }\end{array}$ \\
\hline \multicolumn{7}{|l|}{ Couranas } \\
\hline $\begin{array}{l}\text { 1) Rosa da Silva } \\
\text { Torres - casada com } \\
\text { filhos }\end{array}$ & 1725 & $1742(\mathrm{~T})$ & Vila & 11 (6 h; $5 \mathrm{~m})$ & $\begin{array}{l}\text { Joana, } \\
\text { José, Luís } \\
\text { e Manuel }\end{array}$ & Não \\
\hline
\end{tabular}

...continua

42 Sheila Faria, ao analisar os inventários post-mortem de mulheres libertas (75\% delas de origem africana), em São João Del Rei, constatou que 67\% eram senhoras de escravos. Sheila de Castro Faria, "Sinhás pretas, damas mercadoras: as pretas minas nas cidades do Rio de Janeiro e de São João Del Rey (1700-1850)”, Tese (Professor Titular), Universidade Federal Fluminense, 2004, pp. 209-210. Oliveira computou, também nos inventários post-mortem, que 78,4\% dos 259 libertos africanos da Bahia possuíam escravos, entre 1790 e 1850. Maria Inês Côrtes de Oliveira, O liberto: seu mundo e os outros, São Paulo: Corrupio, 1998, p. 41.

43 AHCSM, $1^{\circ}$ Ofício, livros de notas: $n^{\circ}$ 25, fl. 105-105v; n ${ }^{\circ} 26$, fl. 35v-36v; no 46, fl. 13-13v; $n^{\circ} 47$, fl. 82-82v, 163v-164; n ${ }^{\circ} 48$, fl. 37-37v; no 49, fl. 98v-99; no 57, fl. 17v-18; n 59 , fl. $140 \mathrm{v}-141$; n $n^{\circ} 64$, fl. 1-4; no 67, fl. 1-3; no 69, fl. 99v-100; no 75, fl. 58-58v, 105v-106; $n^{\circ} 78$, fl. 89-89v; no 84, fl. 45-45v; no 85, fl. 146v-147, 138v-139; n ${ }^{\circ} 96$, fl. 131v-132; $n^{\circ}$ 97, fl. 53-53v; $2^{\circ}$ Ofício, livro de notas: $n^{\circ} 3$, fl. 92-92v; $1^{\circ}$ Ofício, livros de testamentos: $n^{\circ} 39$, fl. 128v-130, 136v-138v; n ${ }^{\circ} 46$, fl. 34-36; n ${ }^{\circ} 47$, fl. 34v-37; no 49, fl. 60-64v; no 50, fl. 68v-70v; no 51, fl. 127-129v, 285-287; no 58, fl. 93-96v, 133-136v; no 72, fl. 77-78; $\mathrm{n}^{\circ}$ 73, fl. 30v-32; $1^{\circ}$ Ofício, inventários: cx. 123, auto 2.562; cx. 103, auto 2.141. AEAM, livros: O-3, fl. 103; O-4, fl. 23; O-7, fl. 150-151; Q-16, fl. 139v, 151-151v; testamentaria n 1.166; Pinheiro, “Confrades do Rosário”, pp. 153 n. 67, 150 n. 49, 188-189. 
Quadro 3 - Continuação

\begin{tabular}{|c|c|c|c|c|c|c|}
\hline Couranos forros & $\begin{array}{c}\text { Ano } \\
\text { da sua } \\
\text { alforria }\end{array}$ & $\begin{array}{c}\text { Ano do } \\
\text { testamento } \\
\text { ou outro } \\
\text { documento }\end{array}$ & Localidade & $\begin{array}{l}\text { Número } \\
\text { total de } \\
\text { escravos }\end{array}$ & $\begin{array}{l}\text { Escravos } \\
\text { couranos }\end{array}$ & $\begin{array}{l}\text { Quartação } \\
\text { courá }\end{array}$ \\
\hline $\begin{array}{l}\text { 2) Feliciana da } \\
\text { Fonseca Ribeira*_- } \\
\text { solteira }\end{array}$ & 1736 & $\begin{array}{c}1739 \text { e } \\
1767(\mathrm{~A})\end{array}$ & Vila & $2 \mathrm{~m}$ & $\begin{array}{c}\text { Alforrias } \\
\text { de Rita e } \\
\text { Cecília }\end{array}$ & Sim \\
\hline $\begin{array}{l}\text { 3) Graça da Silva** _ } \\
\text { casada }\end{array}$ & - & $1743(\mathrm{~T})$ & Vila & 3 (2 h; 1 m) & Manuel & NC \\
\hline $\begin{array}{l}\text { 4) Antônia Ferraz de } \\
\text { Azevedo* - casada }\end{array}$ & - & $\begin{array}{l}1729(\mathrm{~B}) \\
1743(\mathrm{~A})\end{array}$ & Vila & $2 \mathrm{~m}$ & $\begin{array}{l}\text { Batismo } \\
\text { de Rita e } \\
\text { alforria de } \\
\text { Maria }\end{array}$ & Sim \\
\hline $\begin{array}{l}\text { 5) Natália Ribeira - } \\
\text { solteira }\end{array}$ & - & $1748(\mathrm{~T})$ & Catas Altas & 6 (3 h; 3 m) & $\begin{array}{c}\text { Sem } \\
\text { informação }\end{array}$ & Não \\
\hline $\begin{array}{l}\text { 6) Tereza Loureira - } \\
\text { casada com filhos } \\
\text { e neta }\end{array}$ & 1731 & $1750(\mathrm{~T})$ & Passagem & 13 (9 h; 4 m) & Ana & Não \\
\hline $\begin{array}{l}\text { 7) Inácia Rodrigues } \\
\text { Serra* }\end{array}$ & - & $\begin{array}{l}\text { 1750; 1756; } \\
1763 \text { (A) }\end{array}$ & Vila & 3 & $\begin{array}{l}\text { Teresa e } \\
\text { Inácia }\end{array}$ & Sim \\
\hline $\begin{array}{l}\text { 8) Maria do Ó - } \\
\text { casada }\end{array}$ & - & $1753(\mathrm{~T})$ & S. Caetano & 10 (5 h; 5 m) & Ana & Sim \\
\hline $\begin{array}{l}\text { 9) Rosa dos Santos - } \\
\text { solteira }\end{array}$ & - & $1756(\mathrm{~T})$ & Mariana & 9 (3 h; 6 m) & $\begin{array}{c}\text { Ana, } \\
\text { Rosaura, } \\
\text { Mariana, } \\
\text { Vitória e } \\
\text { José }\end{array}$ & Sim \\
\hline $\begin{array}{l}\text { 10) Tereza Maria de } \\
\text { Jesus - solteira }\end{array}$ & - & $1758(\mathrm{~T})$ & Mariana & 4 (1 h; 3 m) & Antônia & Sim \\
\hline $\begin{array}{l}\text { 11) Antônia Carvalho } \\
\text { de Barros - casada }\end{array}$ & 1738 & $1760(\mathrm{~T})$ & Passagem & 8 (5 h; 3 m) & José & Não \\
\hline $\begin{array}{l}\text { 12) Rosa Carneiro de } \\
\text { Lima* }\end{array}$ & 1738 & 1764 (A) & Mariana & - & $\begin{array}{l}\text { Alforria de } \\
\text { Josefa }\end{array}$ & Sim \\
\hline $\begin{array}{l}\text { 13) Josefa da Mata - } \\
\text { solteira com filho } \\
\text { e neta }\end{array}$ & - & $1766(\mathrm{~T})$ & Mariana & 4 (1 h; 3 m) & - & - \\
\hline $\begin{array}{l}\text { 14) Marcela Jorge de } \\
\text { Carvalho - solteira }\end{array}$ & 1742 & $1766(\mathrm{~T})$ & Passagem & 5 (3 h; 2 m) & - & - \\
\hline $\begin{array}{l}\text { 15) Escolástica } \\
\text { Pereira Machado - } \\
\text { solteira com } \\
\text { filho e netos }\end{array}$ & 1739 & $1770(\mathrm{~T})$ & Passagem & 4 (3 h; 1 m) & - & - \\
\hline
\end{tabular}


Quadro 3 - Continuação

\begin{tabular}{|c|c|c|c|c|c|c|}
\hline Couranos forros & $\begin{array}{c}\text { Ano } \\
\text { da sua } \\
\text { alforria }\end{array}$ & $\begin{array}{c}\text { Ano do } \\
\text { testamento } \\
\text { ou outro } \\
\text { documento }\end{array}$ & Localidade & $\begin{array}{l}\text { Número } \\
\text { total de } \\
\text { escravos }\end{array}$ & $\begin{array}{l}\text { Escravos } \\
\text { couranos }\end{array}$ & $\begin{array}{l}\text { Quartação } \\
\text { courá }\end{array}$ \\
\hline $\begin{array}{l}\text { 16) Rita Batista - } \\
\text { solteira com filhas }\end{array}$ & - & $1772(\mathrm{~T})$ & Mariana & $1 \mathrm{~m}$ & - & - \\
\hline $\begin{array}{l}\text { 17) Quitéria Botelha } \\
\text { de Carvalho - solteira } \\
\text { com filha e netas }\end{array}$ & 1746 & $1782(\mathrm{~T})$ & $\begin{array}{l}\text { Morro S. } \\
\text { Ana }\end{array}$ & $2 \mathrm{~h}$ & - & - \\
\hline $\begin{array}{l}\text { 18) Roza Ferreira de } \\
\text { Souza - solteira }\end{array}$ & - & $1802(\mathrm{~T})$ & Mariana & $3 \mathrm{~m}$ & - & - \\
\hline $\begin{array}{l}\text { 19) Tereza Francisca } \\
\text { Braga - solteira } \\
\text { com filhos }\end{array}$ & 1742 & $1802(\mathrm{~T})$ & Passagem & 2 (1 h; 1 m) & - & - \\
\hline \multicolumn{7}{|l|}{ Couranos } \\
\hline $\begin{array}{l}\text { 1) Inácio Fagundes - } \\
\text { casado }\end{array}$ & 1726 & $1732(\mathrm{~T})$ & Vila & $9(4 \mathrm{~h} ; 5 \mathrm{~m})$ & $\begin{array}{l}\text { Francisca, } \\
\text { José e } \\
\text { Rita }\end{array}$ & Sim \\
\hline $\begin{array}{l}\text { 2) Gonçalo dos } \\
\text { Santos - solteiro }\end{array}$ & 1754 & $1756(\mathrm{~T})$ & Mariana & $2 \mathrm{~h}$ & $\begin{array}{l}\text { José mina } \\
\text { (courá) }\end{array}$ & Não \\
\hline $\begin{array}{l}\text { 3) Diogo de Souza } \\
\text { Coelho - solteiro } \\
\text { com filha }\end{array}$ & - & $1774(\mathrm{~T})$ & Mariana & 7 (4 h; 3 m) & $\begin{array}{c}\text { Ana, } \\
\text { José e } \\
\text { Domingos }\end{array}$ & Sim \\
\hline $\begin{array}{l}\text { 4) Antônio Pinto } \\
\text { Homem - solteiro }\end{array}$ & 1766 & $1784(\mathrm{~T})$ & Mariana & $1 \mathrm{~h}$ & - & - \\
\hline \multicolumn{7}{|c|}{$\begin{array}{l}\text { (T) = Testamento; }(\mathrm{A}) \text { = Alforria; }(\mathrm{B}) \text { = Batismo. } \\
\text { h = homem; m = mulher. } \\
\text { NC = não consta. } \\
\text { * Nos dados das couranas libertas Feliciana da Fonseca Ribeira, Antônia Ferraz de Azevedo, } \\
\text { Inácia Rodrigues Serra e Rosa Carneiro de Lima, a terceira coluna “Ano do Testamento ou outro } \\
\text { documento” apresenta também a data do documento de alforria (A) de escravos de suas casas. } \\
\text { ** Graça da Silva é declarada como courana no testamento do marido, o liberto José da Silva, } \\
\text { natural da Costa da Mina. }\end{array}$} \\
\hline
\end{tabular}

Em Mariana, entre 1732 e 1802, localizamos 19 testadores courás, em sua maioria moradores na sede do termo (12), além daqueles residentes nos distritos mais próximos, como Passagem (4) e Morro de Santa Ana (1), ou nos mais distantes, como Catas Altas (1) e São Caetano (1). Todos chegaram 
ao Termo de Mariana ainda na primeira metade do século XVIII, sendo que a maioria (14) faleceu antes do final da década de 1770.

Esses lares chefiados por couranos em Mariana contaram com um número relativamente expressivo de escravizados. Somados todos os escravos dos testamenteiros, cada courano teria, em média, 5,47 escravos índice nada irrelevante. A posse escrava entre proprietários da povoação, por exemplo, em 1723, mostrava que a maioria dos senhores de escravos (69,32\%), dentre eles treze forros, tinha entre uma e quatro pessoas escravizadas. ${ }^{44}$ Inácio Fagundes tinha nove escravos, Rosa da Silva Torres e Maria do Ó tinham onze, cada uma, e Tereza Loureira chegava a treze trabalhadores escravos. Esta senhora courana, moradora de Passagem, juntamente com outros dois libertos identificados como da Costa da Mina, o casal Manoel e Josefa Lopes, moradores no distrito de Furquim, foram os três libertos com a maior posse de escravos de que temos notícia em todo o território, entre 1729 e $1790 .^{45}$ Todos os quatro primeiros couranos com maior número de escravos em Mariana (Teresa Loureira, Rosa da Silva Torres, Maria do Ó e Inácio Fagundes) eram casados. O casamento poderia trazer estabilidade e suposta comunhão de objetivos, porém, é importante salientar, tanto Teresa Loureira quanto Rosa da Silva Torres, além de já possuírem bens antes do casamento, também compraram a liberdade dos seus maridos. Na vizinha Vila Rica, Josefa Marques de Carvalho, "mina courana”, também era forra antes do seu segundo casamento com o "mina courano” Teodósio de Carvalho, em 1754, tendo onze escravos em sua casa quando faleceu, em $1789 .{ }^{46}$

44 Maia, “'Quem tem padrinho não morre pagão”, p. 40. Além dos senhores com entre 1 e 4 escravos, encontramos proprietários nas seguintes faixas: 5 a 9 escravos $(18,48 \%) ; 10$ a $19(7,98 \%) ; 20$ a $49(3,78 \%)$; mais de 50 escravos $(0,42 \%)$.

45 AHCSM, $1^{\circ}$ Ofício, cx. 123, auto 2.562, Inventário de Teresa Loureira, 13 dez. 1750, fl. $12-17 \mathrm{v}$; ; livro de registro de testamentos $\mathrm{n}^{\circ} 51$, Testamento de Josefa Lopes, 5 set. 1770 , fl. 277-279; livro de registro de testamentos $n^{\circ}$ 52, Testamento de Manoel Lopes, 5 set. 1770 , fl. 141v-143. Também consultamos registros de testamentos e inventários do AHCSM e no AEAM de 1729 a 1790.

46 Arquivo Eclesiástico da Paróquia de Nossa Senhora do Pilar (AEPNSP), Ouro Preto, cód. 507, Registro de casamento de Teodósio e Josefa, 31 ago. 1754, fl. 6v. Arquivo Histórico do Museu da Inconfidência (AHMI), Ouro Preto, $1^{\circ}$ Ofício, cód. 416, 
Em muitas dessas moradias de libertos couranos, a língua geral de mina era corrente e falada por quase todos os moradores. Entre os escravos que vieram da África, muitos dos quais recém-chegados a Mariana, cerca de $15 \%$ eram centro-ocidentais e quase $85 \%$ eram africanos ocidentais que poderíamos reunir como provenientes da Costa da Mina (mina, courano, cobu, fon, ladano e sabaru). Os couranos chefiavam lares que, em grande parte, eram formados por minas, falantes de língua geral, muitos dos quais integrariam os grupos atualmente identificados como do tronco linguístico gbe. Somados todos os escravizados dos testadores couranos, temos: 50\% de africanos ocidentais; 9\% de africanos centro-ocidentais; 31\% de crioulos; 3\% designados como pardos ou mulatos; e 5\% sem identificação. Havia um equilíbrio de gênero na presença de minas nessas residências: 21 homens e 25 mulheres.

Seguidamente aos africanos ocidentais, como seus donos vindos da Costa da Mina, muitos dos crioulos e pardos ou mulatos eram nascidos nesses domicílios, portanto filhos dos próprios escravos - particularmente das mulheres mina. A liberta courana Marcela Jorge de Carvalho possuía duas casas, ouro lavrado e alguns escravos. Solteira, residia no distrito de Passagem com seus escravos: Quitéria ladá (aladá) e três filhos dela, Felícia e Joaquim, crioulos, e Antônio, mulatinho, e João, crioulo. ${ }^{47} \mathrm{O}$ domínio da língua portuguesa e, talvez, da escrita tornava alguns crioulos elementos necessários nessas casas.

Além da própria dinâmica do tráfico, que garantia a maior oferta de escravos vindos da África Ocidental, nessa região da capitania de Minas e nesse período, houve claro direcionamento dos couranos para a aquisição de escravos minas (85\%) frente aos centro-ocidentais (15\%). Para Maria Inês Cortes de Oliveira, que analisou comportamentos de libertos africanos na Bahia, havia vantagens na aquisição de trabalhadores

auto 8247, livro de testamento v. 14, Testamento de Josefa Marques de Carvalho, 17 set. 1789 , fl. $88-89 \mathrm{v}$.

47 AHCSM, $1^{\circ}$ Ofício, livro de testamento $\mathrm{n}^{\circ}$ 58, Testamento de Marcela Jorge de Carvalho, 2 nov. 1766 (abertura em 11 jun. 1767), fl. 133-136v. 
da mesma nação, pois “não havendo a barreira linguística”, era possível "começar imediatamente a usufruir do produto de seu trabalho, especialmente no caso das 'ganhadeiras'”, ${ }^{48}$ Além disso, a comunicação facilitava também o aprendizado mais rápido do universo da escravidão. Ultrapassar o problema da barreira linguística era importante. Como o mercado local esteve conectado por algumas décadas ao tráfico internacional de escravos, não haveria problemas com a aquisição de africanos que compartilhavam valores comuns, como aconteceu com aqueles falantes de línguas do tronco gbe ou protoiorubás.

Como bem enfatizou o vigário da freguesia de Nossa Senhora do Pilar da sede de Vila Rica de Ouro Preto, quando já se passava a metade do século XVIII, no batizado de novos escravos: "todos são de nação mina de língua geral: e todos assim padrinhos como madrinhas são [moradores] desta freguesia: de que fiz este assento”. ${ }^{49}$

Foi essa proximidade linguística que possibilitou a Felipe courano junto com Manoel ladá (aladá) servirem de intérpretes para Manoel sabarú (savalu) que falava em uma "língua mina” em um ritual de adivinhação na freguesia mineira de Santa Bárbara em $1740 .{ }^{50}$ Esse elemento é um indicador das conexões entre grupos gbes do litoral (courá) e do interior (aladá e savalu) do Golfo do Benim.

Uidá era um centro cosmopolita no litoral africano acostumado a receber muitos outros grupos e povos da Europa e da África, com suas diversidades linguísticas e culturais. A língua portuguesa havia se tornado um dos idiomas do comércio escravista de Uidá, com a formação de intérpretes africanos. Na diáspora americana, a experiência e a habilidade no contato interétnico certamente ajudaram alguns courás

48 Maria Inês Côrtes de Oliveira, "Viver e morrer no meio dos seus. Nações e comunidades africanas na Bahia do século XIX”, Revista Usp, n. 28 (1996), p. 188.

49 AEPNSP, cód. 493, Registro de Batismo de Félix, João, Tomás, Pedro e Mateus minas, 25 jul. 1756, fl. 135v.

50 ANTT, Inquisição de Lisboa apud André Luís Lima Nogueira, "Entre cirurgiões, tambores e ervas: calunduzeiros e curadores ilegais em ação nas Minas Gerais (século XVIII)”, Tese (Doutorado em História das Ciências e da Saúde), Fundação Oswaldo Cruz, Rio de Janeiro, 2013, p. 207. 
no processo de adaptação e como mediadores na interação com outros grupos da Costa da Mina.

Se havia a possibilidade de encontrar com mais facilidade africanos de diferentes grupos étnicos, falantes de línguas do tronco gbe, nos mercados escravistas das duas povoações mineiras, a presença acentuada de courás nas casas desses libertos em Mariana reforça o interesse particular desses forros. Em alguns desses lares, particularmente na primeira metade do século XVIII, os courás escravizados aparecem como os principais moradores, seguidos por outros grupos do interior do Golfo do Benim e posteriormente de outras partes do continente africano.

Ao inventariarmos com atenção todos os escravos que aparecem nos testamentos de libertos couranos de Mariana, nota-se a presença marcante de escravizados do mesmo grupo. Além de serem reconhecidos como mina, muitos eram couranos. ${ }^{51} \mathrm{~A}$ historiadora Fernanda Pinheiro foi a primeira a destacar a presença de escravizados courás nas residências de couranos forros confrades da Irmandade do Rosário dos Pretos de Mariana, entre 1745 e 1808. Além disso, a historiadora revelou o ingresso de muitos senhores e de seus escravos como irmãos da confraria negra e dos oragos estabelecidos na Capela do Rosário da cidade de Mariana. ${ }^{52}$

Além da possibilidade de reunir parentes consanguíneos, aparentados e pessoas conhecidas separados pelo tráfico e pela escravidão, podemos supor que heranças e universos culturais próprios das comunidades litorâneas da África Ocidental, da “terra dos courás”, também fossem elementos importante nesse processo. Ter indivíduos que compartilhavam valores comuns, códigos sociais e mesmas visões de mundo trariam talvez mais segurança na constituição desses "lares africanos”. Além desses, acreditamos que a queda de Uidá e de outras comunidades costeiras, que levaram à dispersão dos habitantes para outras áreas e para

51 Nos nove testamentos de couranos de Mariana e do distrito de Passagem, entre 1732 e 1760, encontramos 59 escravos da Costa da Mina, sendo que 8 deles foram designados apenas como mina. Os demais eram 17 couranos, 5 fons, 2 sabarus e 2 ladanos.

52 Pinheiro, “Confrades do Rosário”, pp. 163-165. 
o exílio, além da luta pela reconquista dos antigos territórios eram fatores a reforçar sentimentos de pertencimento grupal. Alguns desses elementos influenciaram nas escolhas de couranos libertos ao constituírem seus lares na diáspora em Mariana e em Vila Rica.

Ao analisarmos as escolhas dos nove testadores forros da sede de Mariana e do vizinho distrito de Passagem, de 1732 a 1760, podemos perceber que em todas as moradias havia couranos como escravos. Nesse período, temos seis senhoras de nação courá (quatro casadas e duas solteiras) e dois homens forros (um casado e o outro solteiro). Além desses dados, mais três senhoras couranas aparecem a batizar e a conceder alforria a escravas da mesma nação - totalizando nove mulheres proprietárias. Inácio Fagundes faleceu em 1733, em sua casa, no sítio do Fagundes, eram todos, Rita, José e Francisca, da mesma nação do senhor. Quase dez anos depois, na nova moradia de Rosa da Silva Torres, perto da Capela de Santa Ana, encontraríamos os escravos Joana, José, Luís e Manuel, descritos no testamento como courás e, no inventário, alguns deles, como mina-couranos. Naquele mesmo período, Graça da Silva era senhora de Manuel, courá, Rosa, mina, e Antônio, fon - quando o marido faleceu em 1743. O casal de couranos Antônia Carvalha de Barros e Luís da Mota vivia no arraial de Passagem. Em 1760, Antônia ditou seu testamento, nele declarando que possuía, junto com o marido, oito escravos: Antônio, mina, “José courano, Inácio da mesma nação”, Manuel, ladano, Maria, sabaru, Bento, crioulo, e Tomásia, crioula, com sua filha Ana. ${ }^{53}$

Esses e todos os demais casos apresentados no Quadro 3, revelam que, especialmente, ao longo da primeira metade do século, os libertos que se autodeclararam couranos possuíam escravos da mesma nação. Se esse ato demonstra as decisões tomadas por esses forros, ele também aponta para o contínuo reforço dessa identidade de nação, mais circunscrita. Não era um comportamento isolado. A cada chegada de indivíduos reconhecidos como courás e que eram comprados e incorporados a

53 AHCSM, $1^{\circ}$ Ofício, livro de testamento n ${ }^{\circ} 49$, Testamento de Antônia Carvalha de Barros, 29 mar. 1760 (abertura em 11 abr. 1761), fl. 60-63v. 
essas casas, chefiadas por africanos, pode ter ocorrido um processo de reatualização do sentimento de pertencimento à referida nação. Essa (re)construção identitária entre aqueles que se reconheciam como couranos ultrapassava, cotidianamente, os muros e as paredes das residências de Mariana e de Vila Rica.

Em Vila Rica de Ouro Preto, localizamos doze testamentos de libertos de nação courana entre 1744 e 1803. De modo geral, esses documentos foram escritos a partir da década de 1770 - nove couranos assim o fizeram -, depois de muitas décadas como moradores de Vila Rica, particularmente, da freguesia do Pilar. Em sua maioria, eles também chegaram à sede da capitania de Minas Gerais na primeira metade do século XVIII, como informam as menções aos seus nomes em diversos documentos: atas de batismo de seus escravos e registros de casamento e de admissão em irmandade. A liberta courana Rosa Moreira, por exemplo, foi declarada como escrava de Manuel Moreira quando se inscreveu, oficialmente, na Irmandade do Rosário dos Pretos do Pilar de Vila Rica, em 1730. Ela, provavelmente, participou da grande e opulenta festa do Triunfo Eucarístico (1733), organizada por seus pares, com um cortejo que teve início na Capela do Rosário indo em direção à nova Matriz do Pilar. Em 1744, estava liberta e mencionou que era solteira e tinha quatro filhos. Duas eram casadas, sendo que sua filha Ângela Moreira residia na comarca do Serro do Frio, além do filho Félix, pardo forro, e de Clara que ainda era escrava do licenciado Pedro de Almeida - e que a mãe desejava ter recursos para alforriar. Rosa declarou ser "natural da Costa da Mina de uma terra chamada Coura” e foi batizada no Arcebispado da Bahia antes de chegar a Vila Rica. ${ }^{54}$

Em janeiro de 1756, o minerador José Nunes, preto forro, muito enfermo, encontrava-se instalado na casa de Antônio Lopes Jorge, com quem manteve convívio e negócios. O courano liberto José Nunes

54 AEPNSP, cód. 506, Registro de óbito com traslado do Testamento de Rosa Moreira, 25 ago. 1744 , fl. 117-118. 
vendeu uma parte da mina de ouro situada no "Morro chamado o do Ramos” para Antônio Jorge que, por sua vez, lhe tinha emprestado os "trastes" que usava no pequeno comércio (uma venda de molhados) que José Nunes mantinha. O seu único escravo era “José de nação Mina”, que o liberto havia comprado, mas que, até aquele momento, não tinha quitado. ${ }^{55}$ Em 1738, o escrivão da Irmandade do Rosário dos Pretos da freguesia do Pilar registrava a matrícula de Luiza courana como escrava. Em 1745, encontramos a courana Luiza Felizarda da Glória ainda como escravizada do licenciado francês Antônio de Labredene e sua esposa Maria Felizarda da Glória. Em 1751, quando Luiza é novamente convidada para ser madrinha de batismo na Igreja Matriz do Pilar, ela consta como Luiza Felizarda, preta forra. ${ }^{56}$ Quase quatro décadas depois, em 1789, a senhora Luiza Felizarda mostrava ter amealhado recursos suficientes para adquirir uma morada de casas, "metade térreas e metade assoalhada com seu quintal, e todos os mais pertences”, na ponte do Rosário, peças em ouro e quatro escravos: Ana, Maria e Francisco, crioulos, e Joaquim, de "nação coura". ${ }^{57}$ Além do escravo de sua nação, ela teceu relações com escravos de outros couranos libertos. Em 1755, Luiza Felizarda foi convidada para ser madrinha da pequena Vicência, filha de Antônia, escrava da liberta Rita da Cruz que, igualmente, era courana (Quadro 4). ${ }^{58}$

55 AEPNSP, cód. 1.923, Testamento de José Nunes, 15 jan. 1756 (abertura em 16 jan. 1756), fl. 65v-66.

56 AEPNSP, cód. 98, Registro de entrada de Luiza courana na Irmandade do Rosário dos Pretos de Vila Rica, 1738, fl. 4v. No documento, Luiza consta como escrava de “Antônio de Labidrene e sua esposa”. AEPNSP, cód. 493, Registros de Batismo de Jozeph mina e Ephigenia inocente, 31 jan. 1745 e 23 ago. 1751, fl. 12 e 82v.

57 Arquivo da Casa dos Contos (ACC), Ouro Preto, v. 14, rolo 2004-0558, fotograma 0769, Testamento de Luiza Felizarda da Glória, 12 mar. 1789 (aberto em 28 out. 1789), fl. 99-101v.

58 AEPNSP, cód. 493, Registro de Batismo de Vicência inocente, 24 set. 1755, fl. 120. Em 1759, a preta forra Antônia Ferreira deu o nome de Luiza, mina, no batismo de sua nova escrava. O padre destacou que o padrinho era Lourenço Courâ, preto forro, morador na Passagem e a madrinha era Luiza Felizarda da Glória, "preta também Courá forra” (AEPNSP, cód. 493, Registro de Batismo de Luiza mina, 26 ago. 1759, fl. 155). 
Quadro 4

Couranos libertos senhores de outros couranos, Vila Rica ${ }^{59}$

\begin{tabular}{|c|c|c|c|c|c|}
\hline Couranos forros & $\begin{array}{c}\text { Primeira } \\
\text { menção ao } \\
\text { nome }\end{array}$ & $\begin{array}{c}\text { Ano do } \\
\text { testamento } \\
\text { ou outro } \\
\text { documento }\end{array}$ & $\begin{array}{l}\text { Número de } \\
\text { escravos }\end{array}$ & $\begin{array}{l}\text { Escravos } \\
\text { couranos }\end{array}$ & Quartação \\
\hline
\end{tabular}

Couranas

\begin{tabular}{|c|c|c|c|c|c|}
\hline $\begin{array}{l}\text { 1) Rosa Moreira - solteira } \\
\text { com filhos }\end{array}$ & 1730 & $1744(\mathrm{O} ; \mathrm{T})$ & $\begin{array}{c}\text { Sem } \\
\text { informação }\end{array}$ & - & - \\
\hline $\begin{array}{l}\text { 2) Maria Ferreira do } \\
\text { Rosário - viúva }\end{array}$ & - & $1764(\mathrm{~T})$ & 4 (2 h; 2 m) & - & Sim \\
\hline $\begin{array}{l}\text { 3) Joana Marques } \\
\text { dos Reis - viúva }\end{array}$ & 1735 & $\begin{array}{c}1779(\mathrm{~T}) \\
1753(\mathrm{~B})^{*}\end{array}$ & $\begin{array}{c}13 \\
(7 \mathrm{~h} ; 6 \mathrm{~m})\end{array}$ & $\begin{array}{c}\text { Teodósia } \\
\text { courana (B) }\end{array}$ & - \\
\hline $\begin{array}{l}\text { 4) Rita da Cruz - } \\
\text { solteira com filhos }\end{array}$ & 1737 & $1779(\mathrm{~T})$ & 3 (1 h; 2 m) & $\begin{array}{l}\text { Joaquina, } \\
\text { Domingas } \\
\text { e Antônia } \\
\text { crioula }\end{array}$ & Sim \\
\hline $\begin{array}{l}\text { 5) Josefa Marques de } \\
\text { Carvalho - casada }\end{array}$ & 1724 & $1789(\mathrm{~T})$ & $\begin{array}{c}11 \\
(8 \mathrm{~h} ; 3 \mathrm{~m})\end{array}$ & - & Não \\
\hline $\begin{array}{l}\text { 6) Luiza Felizarda } \\
\text { da Glória - solteira }\end{array}$ & 1738 & $1789(\mathrm{~T})$ & 4 (2 h; 2 m) & $\begin{array}{l}\text { Joaquim } \\
\text { courá }\end{array}$ & Sim \\
\hline $\begin{array}{l}\text { 7) Rosa Maria de Jesus - } \\
\text { solteira com filha e neto }\end{array}$ & - & $1792(\mathrm{~T})$ & 7 (2 h; 5 m) & - & Sim \\
\hline $\begin{array}{l}\text { 8) Josefa Maria de Lima - } \\
\text { solteira }\end{array}$ & 1742 & $1794(\mathrm{~T})$ & $\begin{array}{c}\text { Sem } \\
\text { escravos }\end{array}$ & - & - \\
\hline $\begin{array}{l}\text { 9) Luiza Ramos - solteira } \\
\text { com filhos e neto }\end{array}$ & 1738 & $\begin{array}{l}1744(\mathrm{~B}) \\
1797(\mathrm{~T})\end{array}$ & 8 (3 h; 5 m) & $\begin{array}{c}\text { Inácia } \\
\text { courana (B) }\end{array}$ & - \\
\hline $\begin{array}{l}\text { 10) Antônia Vieira [de } \\
\text { Campos] - casada }\end{array}$ & 1743 & 1776 (I) & $1 \mathrm{~m}$ & - & - \\
\hline $\begin{array}{l}\text { 11) Inácia Ramos } \\
\text { [dos Reis] }\end{array}$ & 1738 & 1750 (I) & 2 (1 h; 1 m) & - & - \\
\hline $\begin{array}{l}\text { 12) Sebastiana Ramos } \\
\text { [dos Reis] }\end{array}$ & 1741 & 1783 (I) & $1 \mathrm{~m}$ & - & - \\
\hline $\begin{array}{l}\text { 13) Micaela da Costa } \\
\text { Fagundes - } \\
\text { solteira com filha e netos }\end{array}$ & $1766^{* *}$ & $1803(\mathrm{~T})$ & $1 \mathrm{~h}$ & - & Sim \\
\hline
\end{tabular}

...continua

59 AEPNSP, cód. 96, fl. 44v e 55v; cód. 97, fl. 1v, 4, 48v, 51v e 60; cód. 98, fl. 1v, 4v, 27v e 28v; cód. 491, fl. 65v; cód. 492, 25 jun. 1737; cód. 493, fl. 5-5v, 59, 102v-103; cód. 506, fl. 35, 117-8; cód. 507, fl. 6v, 51v; cód. 1.923, fl. 65-66; cód. 1.926, fl. 122-127v; cód. 1.930, fl. 202v-204; cód. 1.931, fl. 169v-172v; cód. 1.933, fl. 168v-169; livro 1.934, fl. 47-48v. AHMI, livro de testamento v. 14, fl. 88-89v; $1^{\circ}$ Ofício, cód. 416, auto 8.247, Inventário; AHMI, testamento 2.003 auto 12, fl. 36-39v. ACC, v. 14, rolo 2004-0558, fotograma 0769. AEAM, armário 3, auto 505, de genere et moribus. 
Quadro 4 - Continuação

\begin{tabular}{|c|c|c|c|c|c|}
\hline Couranos forros & $\begin{array}{c}\text { Primeira } \\
\text { menção ao } \\
\text { nome }\end{array}$ & $\begin{array}{c}\text { Ano do } \\
\text { testamento } \\
\text { ou outro } \\
\text { documento }\end{array}$ & $\begin{array}{l}\text { Número de } \\
\text { escravos }\end{array}$ & $\begin{array}{l}\text { Escravos } \\
\text { couranos }\end{array}$ & Quartação \\
\hline \multicolumn{6}{|l|}{ Couranos } \\
\hline 1) José Nunes - solteiro & - & $1756(\mathrm{~T})$ & 1 & - & Sim \\
\hline $\begin{array}{l}\text { 2) Teodósio Correia de } \\
\text { Andrade - viúvo }(\mathrm{T})\end{array}$ & 1736 & $1801(\mathrm{~T})$ & $3 \mathrm{~h}$ & - & Sim \\
\hline \multicolumn{6}{|c|}{$\begin{array}{l}\text { (T) = Testamento; }(\mathrm{I})=\text { Irmandade; }(\mathrm{B})=\text { Batismo; }(\mathrm{O}) \text { = Óbito. } \\
\text { h = homem; m = mulher. } \\
\text { * Informação sobre os escravos de Joana Marques dos Reis foi recolhida nos registros de } \\
\text { batismos. } \\
\text { ** Primeira menção encontrada no casamento da filha, em } 1766 \text {. }\end{array}$} \\
\hline
\end{tabular}

Os testamentos revelam um período da vida desses africanos, a partir da década de 1770, em que eles, em sua maioria, encontravam-se em idade mais avançada, alguns com muitas décadas vividas na povoação, onde passaram da escravidão para a liberdade. Consequentemente, esses documentos revelam mudanças ocorridas nessas casas, como compra ou venda de trabalhadores escravos e o nascimento dos filhos de uma parcela desses escravizados. De modo geral, encontramos nessas residências $54,5 \%$ de crioulos (11 homens e 13 mulheres), 22,7\% de africanos ocidentais (8 homens e 2 mulheres), 4,5\% de africanos centro-ocidentais ( 2 homens) e, para 18,1\%, não obtivemos informação (5 homens e 3 mulheres). Em maio de 1792, por exemplo, a courana forra Rosa Maria de Jesus, moradora no Morro de Nossa Senhora da Piedade, ditou o seu testamento. Rosa tinha sido batizada na freguesia de Nossa Senhora do Antônio Dias, em Ouro Preto. Ela tinha vivido parte de sua vida com um homem livre, de certa importância - pois ostentava o título de capitão -, com quem teve uma filha, Antônia da Rocha de Jesus, que lhe deu um neto, Francisco de Almeida Pinto, que se tornou padre. Rosa Maria de Jesus, de escrava tornou-se senhora e proprietária de sua casa. Ainda doente, um mês depois de ditar o seu testamento, ela detalhou, em um codicilo, as suas últimas vontades em relação aos trabalhadores escravos 
de sua propriedade. A maioria desses seus escravos estava em processo de coartação, mas a senhora orientava a sua filha e herdeira para que tornasse todos ao cativeiro, caso não quitassem suas alforrias, convertendo o pouco valor pago em “jornais” que fossem devidos. Predominantemente, eram crioulos: Josefa e sua filha Rosa, Domingos, Vicente, Bárbara e Maria que tinha uma filha recém-nascida chamada Ana "cabrinha”, ${ }^{60}$

A casa de Rosa Maria de Jesus é um bom exemplo dos domicílios escravistas da sede de Vila Rica, no final do século XVIII. Casas formadas por um número expressivo de escravos nascidos na América portuguesa, grande parte deles, decerto, filhos de escravos das próprias casas. Cenário bem diferente de décadas anteriores, como o existente na moradia da viúva Maria Ferreira do Rosário, no Morro da Queimada, na mesma freguesia onde habitava a também courana Rosa Maria de Jesus. Em 1764, Maria Ferreira do Rosário era senhora de Micaela, mina, Francisco, nagô, e de Ana Maria, crioula, e seu filho Manuel, crioulo. ${ }^{61}$

Nesses lares dirigidos por couranos forros, encontramos também a presença de trabalhadores escravos da mesma nação do senhor, como em Mariana. Contudo, as informações dos testamentos, em Vila Rica, mais encobrem do que revelam a nação dos escravizados das casas chefiadas por libertos - o que torna o trabalho do historiador mais complexo. Por exemplo, temos os casos de duas libertas couranas, Joana Marques dos Reis, moradora da freguesia do Pilar, no Morro dos Agrelos, e de Luiza Ramos dos Reis, que residia no Morro do Pau-Doce e frequentava a mesma freguesia. Em 1779, Joana Marques declarou ser viúva, não ter tido filhos, e que todos os seus bens foram adquiridos pela sua "indústria e trabalho, sem que meu marido concorresse com alguns” e que o seu companheiro sempre "esteve sujeito ao cativeiro, servindo ao senhor".

60 AHMI, livro de testamento 2.003, 12, Testamento e codicilo de Rosa Maria de Jesus, testamento de 13 maio 1792 e codicilo de 17 jun. 1792 (abertos em 18 jun. 1792), fl. 36v-39v. AEAM, armário 3, auto 505, Processo De genere et moribus de Francisco de Almeida Pinto.

61 AEPNSP, cód. 1.926, Testamento de Maria Ferreira do Rosário, 3 set. 1764 (abertura em 15 nov. 1764), fl. $122-127 \mathrm{v}$. 
Joana Marques, ao contrário do marido, teve mais habilidade de conseguir pecúlio e negociar a comprar da própria alforria.

O casamento, quando ainda estava na condição de escrava, aconteceu em 1735. Três anos depois, ela aparece como liberta em documentos da freguesia do Pilar, na sede de Vila Rica. ${ }^{62}$ Além disso, pelo seu trabalho, conseguiu adquirir trabalhadores escravos que, posteriormente, passaram a trabalhar para o seu antigo senhor, o potentado capitão-mor Antônio Ramos dos Reis, que devia pagar os jornais à liberta Joana. Em 1779, quando Joana Marques ditou seu testamento, ela estava viúva, deixava missas pelas almas de seus escravos falecidos e tinha feito a venda de todos os seus bens para Francisco Martins Pereira, que ela também nomeou como seu herdeiro. ${ }^{63}$

A estratégia de venda de seus bens impossibilitou-nos conhecer os escravos que a senhora conseguiu adquirir enquanto mulher liberta. Pelos documentosbatismaisda freguesiado Pilardas décadasde1740e1750, sabemos os nomes de alguns deles: Domingas, Paulo, Manuel, angola, e Teodósia, que era courana. Contudo, nos livros de matrículas dos confrades da Irmandade do Rosário dos Pretos da freguesia do Pilar, descobrimos que Joana era possuidora de treze trabalhadores escravos oficialmente inscritos nessa agremiação religiosa, alguns deles também se alforriaram como a senhora courana. Eram eles Paulo, Manino, Inácio, mina, Teodósia, courana, Maria, nagô, Maria, crioula, Antônia, ladá e Antônio. Na matrícula dos demais escravos de Joana Marques, no livro da Irmandade do Rosário, foi acrescentada, posteriormente, a palavra forro/forra. Eram eles: Domingas, Sebastiana, Matias, Pedro, Manoino, completando os quinze membros de sua casa que encontramos. ${ }^{64}$ São fragmentos da história de Joana Marques que conseguimos recompor. O número de trabalhadores em sua casa reflete sua prosperidade econômica

62 AEPNSP, cód. 506, Registro de casamento de Joana e Manuel escravos, 26 ago. 1735, fl. 6v., cód. 491, Registro de Batismo de Gregório inocente, 19 mar. 1738, fl. 34.

63 AEPNSP, cód. 1.931, Testamento de Joana Marques dos Reis, 20 mar. 1779 (abertura em 11 mar. 1787), fl. 169v-172v.

64 AEPNSP, cód. 98, Livro de Entradas, profissões e termos da Irmandade de Nossa Senhora do Rosário de Vila Rica, freg. Pilar, (1734-1781), fl. 27v. 
como ocorreu com as senhoras courás libertas de Mariana: Teresa Loureira (treze), Rosa da Silva Torres (onze) e Maria do Ó (onze).

Luiza Ramos, outra liberta, de nação courana, declarou-se solteira, com dois filhos, um neto e sete trabalhadores escravos em sua casa, quando registrou o seu testamento em 1797 - mais de seis décadas depois de sua chegada a Vila Rica. Outrora, ainda na década de 1730, ela foi parceira de cativeiro da também courana Joana Marques dos Reis, ambas escravas nas lavras minerais do capitão-mor Antônio Ramos dos Reis. Na década de 1740 ela já era livre, quando nasceram seus dois filhos, Maria Luiza e Luís. ${ }^{65}$ Naquela época, ela também estava agregada à casa do seu antigo senhor, no Morro do Ramos (atual Veloso). Em 1744, dois anos antes do nascimento da filha, Luiza Ramos conseguiu adquirir uma trabalhadora escrava, provavelmente bem jovem, cujo valor era mais baixo no mercado escravista. Naquele ano, Luiza a levou para ser batizada na opulenta matriz da freguesia do Pilar - a jovem africana recebeu o nome de Inácia e foi declarada, na ata batismal, como pertencente à nação courana. ${ }^{66}$ Inácia não estava entre os escravos mencionados pela senhora Luiza Ramos quando ditou o seu testamento, em 1797. ${ }^{67}$ Se sabemos os seus nomes (Pedro, Manuel, Páscoa e seu filho Teotônio, Teresa e sua filha Rita), não temos nenhuma informação sobre suas nações. ${ }^{68}$

Em alguns desses lares chefiados por courás a aquisição de trabalhadores também courás tinha como objetivo a reunião de parentes consanguíneos, tios, sobrinhos e irmãos que também teriam sido escravizados no litoral do Golfo do Benim e que viveram os horrores do tráfico transatlântico até chegarem a Minas Gerais. Em 1774, o courano liberto Diogo de Souza Coelho estava doente e preparou o seu testamento no

65 AEPNSP, cód. 493, Registros de Batismo de Maria Luiza e Luís inocentes, 27 ago. 1746 e 30 jan. 1750, fl. 29 e 68.

66 AEPNSP, cód. 493, Registros de Batismo de Inácia courana, 7 jun. 1744, fl. 5-5v.

67 AEPNSP, cód. 98, Registro de entrada de Ignácia escrava de Luiza Ramos na irmandade do Rosário dos Pretos de Vila Rica, 1744, fl. 48v. Consta, à margem esquerda do documento, que Inácia teria falecido em 9 fev. 1785.

68 AEPNSP, cód. 1.934, Testamento de Luiza Ramos, 7 jul. 1797 (abertura em 29 jan. 1800), fl. 47-48v. 
qual declarou ser solteiro e que legava seus bens a sua filha Paula. Havia quartado vários dos seus trabalhadores escravizados. Entre seus escravos e ex-escravos estavam: Ana, José (65 anos) e Domingos (60 anos), todos couranos; José mina (60 anos); Maria (14 anos), Manuel (16 anos) e Maria (30 anos), todos crioulos. ${ }^{69}$ Domingos, além de pertencer à casa do senhor Diogo, era também sobrinho dele. ${ }^{70}$ Domingos chegou à Mariana por volta de 1730, foi batizado como escravo de Manuel Ribeiro Moreira. ${ }^{71}$ Seu tio, Diogo de Souza, mencionou ter sido batizado no arraial de Antônio Pereira, distrito um pouco distante e pertencente ao termo de Mariana e, quando se libertou, negociou com Manuel Ribeiro Moreira a venda do sobrinho, que passou a viver sob sua autoridade e companhia.

\section{Considerações finais}

Tanto em Mariana quanto em Vila Rica, enquanto havia africanos reconhecidos como couranos nos mercados escravistas da região, muitos libertos desse grupo escolheram adquiri-los como trabalhadores escravos. Era, decerto, uma opção em uma conjuntura diferente da vivenciada pelos grupos litorâneos do Golfo do Benim. Conforme apontou o capitão de navio inglês, Snelgrave, após várias viagens para aquela costa africana, no início do século XVIII, a principal forma de escravização era a do cativeiro pela guerra - fosse motivada por conflitos políticos ou com o objetivo exclusivo de escravização, para a venda final aos europeus. ${ }^{72} \mathrm{O}$ escravizado era geralmente estrangeiro. No caso dos grupos litorâneos, supostamente, havia o entendimento de que não se escravizava os habitantes sob um determinado governante. Em Uidá

69 AEAM, livro Q-16, Testamento de Diogo de Souza Coelho, 11 fev. 1774, fl. 150-151v. AHCSM, $1^{\circ}$ Ofício, cx. 103, auto 2141, Inventário de Diogo de Souza Coelho, 16 fev. 1774.

70 Pinheiro, “Confrades do Rosário”, p. 163.

71 AEAM, livro O-4, Registro de Batismo de Domingos adulto, 6 jul. 1733, fl. 78.

72 William Snelgrave, A New Account of Some Parts of Guinea and the Slave-Trade, Londres: James, John, and Paul Knapton, 1734, p. 159. 
havia uma proibição de escravização da população, permitida apenas em casos punitivos e judiciais. ${ }^{73}$ Essa interdição, por outro lado, não impedia o cativeiro dos habitantes de reinos vizinhos. ${ }^{74}$ Provavelmente foi a partir de 1727 que o maior número de habitantes do litoral do Golfo do Benim foi escravizado e traficado para a América, particularmente, para os domínios portugueses. A expansão do Daomé ${ }^{75}$ sobre o litoral promoveu uma maior diáspora dos povos chamados pelos portugueses de courás ou couranos e produziu maior instabilidade na região ao longo do século XVIII. Foi essa conjuntura que fez chegar a Minas Gerais muitos habitantes daquela região africana.

A valorização e a (re)construção de uma identidade courana em Minas Gerais e as evidências de variados vínculos estabelecidos entre aqueles que declaravam tal identidade mostram que havia um processo de mudança acontecendo. A aquisição de escravos couranos pelos libertos desse mesmo grupo revela uma possível quebra da proibição de escravização que se verificava em solo africano. No entanto, é necessário lembrar que a conjuntura

73 Como bem lembrava o referido capitão de navio inglês, esses povos litorâneos não tendiam a vender sua população. Isso poderia acontecer nos casos punitivos (crimes, conflitos e dívidas), sendo que penas capitais poderiam ser convertidas na expulsão do indivíduo daquela sociedade para o tráfico de escravos. Snelgrave, A New Account, pp. 158-159. Estudiosos como Lovejoy e Claude Meillassoux, que refletiram sobre a questão da escravidão no continente africano, apontaram para a natureza fundamental do escravo como elemento externo, estrangeiro. Os autores apontam também as demais formas de escravização, por nascimento, origem e penas judiciais. Paul E. Lovejoy, A escravidão na África: uma história de suas transformações, Rio de Janeiro: Civilização Brasileira, 2002, pp. 29-32; Claude Meillassoux, Antropologia da escravidão: o ventre de ferro e dinheiro, Rio de Janeiro: Jorge Zahar, 1995.

74 Tanto a guerra organizada pelos governantes, quanto o banditismo promovido por pequenos grupos, levaram ao aprisionamento e venda de hulas e huedás aos traficantes europeus, por exemplo, como os eventos que envolveram Grande Popo e Uidá no final do século XVII e início do século XVIII. Sobre conflitos e a questão identitária no litoral do Golfo do Benim, ver: Luis Nicolau Parés, “The Hula 'Problem': Ethnicity in The Pre-colonial Slave Coast” in Toyin Falola e Matt D. Childs (orgs.), The Changing Worlds of Atlantic Africa: Essays in Honor of Robin Law (Durham: Carolina Academic Press, 2009), pp. 323-346; Abiola Félix Iroko, Les Hula, du XIVe au XIX siècle, Cotonou: Les Nouvelles Editions du Benin, 2001.

75 Sobre a expansão do Daomé sobre o litoral ver: Law, Ouidah; e The Slave Coast of West Africa, 1550-1750: The Impact of the Atlantic Slave Trade on an African Society, Oxford: Claredon Press, 1991; Isaac Adéagbo Akinjogbin, Dahomey and its Neighbours (1708-1818), Cambridge: The University Press, 1967; Verger, Fluxo e refluxo. 
dos povos africanos encontrada no Brasil não eram as mesmas vivenciadas no Golfo do Benim. Os africanos chegavam aos povoados mineiros como novos escravizados a serem oferecidos no mercado escravista.

No vocabulário da Língua Geral de Mina falado nessa região mineira, se não havia guerra na "terra de branco", os africanos minas apontavam diferenças entre a escravidão de suas terras natais e a vivenciada em Minas Gerais: "os brancos castigam (açoitam) muito os escravos (Hi hà bouno, hè nachuhé acrú susû)". ${ }^{76}$ Ter um africano como senhor talvez vislumbrasse uma relação entre senhor e escravo diferenciada.

A dinamicidade das povoações garimpeiras, particularmente dos núcleos urbanos de Vila Rica e Vila do Carmo, propiciou a inserção dos couranos em diversas atividades econômicas que garantiram, a alguns, a obtenção de bens como casas, pequenos comércios, minas de ouro e serviços de mineração, plantações agrícolas e, principalmente, a aquisição de trabalhadores escravos. Ao reunirmos as informações sobre estes libertos, constatamos que, em sua maioria, os couranos tiveram bastante habilidade nos negócios, o que os levou a serem, entre os africanos ex-escravos, aqueles que tiveram o maior contingente de escravizados. De ex-escravos, passaram a ser senhores de suas casas. Nelas, encontramos pequenas comunidades africanas compostas por indivíduos da mesma origem. Os couranos adquiriram outros couranos como escravizados, o que, certamente, reforçava ainda mais a autoridade no âmbito do grupo étnico.

Podemos supor que havia algo mais motivando a aquisição de pessoas pelos libertos courás no mercado de trabalhadores escravos de Ouro Preto e Mariana. Parentesco consanguíneo, amizades pretéritas e heranças culturais compartilhadas, decerto influenciaram as escolhas e a constituição desses novos lares africanos em terras mineiras. Foi o que levou o senhor Diogo, liberto courano, a comprar o escravizado Domingos, que era seu sobrinho. Seria, neste caso, uma forma de proteção possível no contexto escravista na diáspora.

76 Castro, A língua mina-jeje no Brasil, p. 118. 
Além disso, o parentesco gerado pelo batismo cristão, por exemplo, analisado sob a perspectiva das redes relacionais, demonstra que alguns desses lares se conectavam a outros lares de couranos, formalmente, pela escolha de padrinhos para o ritual. ${ }^{77}$ Casamentos, participação religiosa nas irmandades, transações comerciais, as sociabilidades nas vendas e nas casas, revelam espaços e instituições, nos quais a nação courá ou courana se fez presente e se constituía como uma identidade de grupo em Mariana e Vila Rica.

Em algumas das moradias, a identificação da maioria dos africanos pertencentes ao mesmo grupo identitário do senhor contrastava com a presença de africanos portadores de identidades que remetiam ao interior do Golfo do Benim: fons, aladanos, sabarus e cobus - o que aponta para um claro sentido de pertencimento e também de contraste identitário. Por outro lado, se havia uma demarcação de fronteira identitária entre os grupos do litoral e os do interior daquela região africana, no novo contexto das povoações americanas, o contato entre esses grupos foi propiciado pelas proximidades linguísticas, culturais e mesmo pelo intercâmbio baseado no comércio e no tráfico transatlântico. Passaram a ser reconhecidos e a se reconhecerem, então, de modo mais genérico, como vindos de uma região africana que o Império Português veio a incluir na chamada Costa da Mina. Assim, os courás podiam ser reconhecidos como vindos da Costa da Mina e, consequentemente, identificados como africanos mina e, mesmo, como um subgrupo mina - o que pode revelar a presença, demograficamente, mais expressiva desses indivíduos em algumas regiões da capitania.

Recebido em 16 jan. 2019

Aprovado em 26 set. 2020

doi: 10.9771/aa.v0i62.29127

77 Maia, "De reino traficante a povo traficado”, cap. 3; e “O apadrinhamento de africanos em Minas Colonial”, pp. 47-48. 
O artigo acompanha um grupo de libertos africanos, nomeado nas fontes portuguesas como courás, couranos ou variantes, para entender como constituíram suas casas em dois importantes núcleos urbanos da capitania de Minas Gerais ao longo do século XVIII. A economia do ouro possibilitou uma significativa posse de trabalhadores escravos para alguns desses senhores negros. O estudo desvenda a origem desses escravizados e como muitos desses lares mantiveram uma estreita relação com o passado africano desse grupo. De forma comparativa e também conectada, percebeu-se como as duas povoações vizinhas possuíam grupos de africanos forros que, além da alforria, adquiriram bens: casas, estabelecimentos comerciais, minas de ouro e, principalmente, trabalhadores escravos do mesmo grupo étnico.

Diáspora africana | Libertos | Escravidão | Identidade étnica | Posse escravista

\section{Reinforcing Identity and Authority: Houses of Freed Courás in Vila Rica and Mariana in the 18th CENTURY}

This article discusses a group of freed African people identified in Portuguese sources as Courás or Couranos, seeking to understand how they formed their homes in two important urban centers of the Captaincy of Minas Gerais during the eighteenth century. The gold-mining economy facilitated the acquisition of significant numbers of enslaved laborers by black masters. The study examines the origin of these enslaved people and the way in which many of these households maintained a close relationship with their African past. Using a comparative and connected approach, this paper shows that in both of the two neighboring towns there were enclaves of freed Africans who, in addition to obtaining manumission, also acquired various forms of property, including houses, commercial establishments, gold mines and especially, enslaved people of the same ethnic group.

African diaspora | African freed people | Slavery | Ethnic identity | Slave ownership 